\title{
La compra por Extremadura del privilego de voto en las Cortes de Castilla
}

\author{
José Antonio Ballesteros Dízz
}

\section{RESUMEN:}

En este artículo se estudia cómo la Provincia de Extremadura consiguió, en 1651, el privilegio del voto en las Cortes de Castilla mediante una compra a la Hacienda Real. También se estudia la relación entre las oligarquías urbanas, los concejos de las ciudades y la representación en Cortes, y como todo ello se produce dentro del pro-

ceso de afirmación del poder real que caracteriza al Estado moderno. La incorporación de Extremadura a las Cortes de Castilla, que siguió a

la de Galicia, muestra el paso de una representación ciudadana a una representación territorial.

\begin{abstract}
This article studies how the Province of Extremadura obtained, in 1651, the privilege of the vote in the Parlament of Castilla thanks to a purchage to the Royal Tresaury. Is also studies the relationship among the urban oligarchies, the council of de towns and the representation in the Parlament, an d as everything happens within the process of affirmation of the royal power which characterizes the Modern state. The incorporation of Extremadura to the Parlament of Castilla, which follows to Galicia's, show the transition of a representation towards a territorial representation.
\end{abstract}

\section{INTRODUCCIÓN}

De origen medieval, las Cortes castellanas se organizaron como una asamblea de representantes de los estamentos sociales, la cual era convocada por el Rey. En su configuración moderna se integraban en ella los miembros de la Curia Regia y los representantes de diversas ciudades y villas del reino; se convocaban y reunían para tratar asuntos importantes, como era recibir juramento del rey, reconocer y jurar al heredero de la Corona, debatir sobre problemas sucesorios, establecer servicios para contribuir a financiar la Hacienda Real (motivo este de la mayor parte de las convocatorias); en la convocatoria de las Cortes se incluía una pequeña minuta referente a los asuntos que presentaba la Corona a las Cortes para su 
debate, y durante la asamblea, por parte de los procuradores, se exponían al Rey una serie de peticiones, bien con iniciativas que se proponian a la Monarquía 0 de quejas y agravios propiciados por oficiales reales o por decisiones reales. Aunque en las Cortes se veían ocasionalmente leyes, era para el conocimiento de los procuradores, nunca para recoger y reflejar sus opiniones, pues las Cortes de Castilla nunca compartieron con el Rey la facultad jurisdiccional de la Corona, y por ello no pueden ser consideradas como asambleas legislativas.

El fortalecimiento del poder real, una de las características del Estado moderno, se manifestó también en las Cortes, y lo hizo aplicando sobre ellas una doble reducción, por una parte se limitó el número de ciudades que se convocaban, fijándose, en el año 1442, que solamente participasen diecisiete; Burgos, León, Zamora, Toro, Salamanca, Ávila, Valladolid, Soria, Segovia, Madrid, Toledo, Cuenca, Guadalajara, Murcia, Sevilla, Córdoba y Jaén, incorporándose Granada en el año 1506, y con esta plantilla las Cortes castellanas llegaron hasta el primer tercio del siglo XVII, cuando se modificó esta composición urbana al conseguir su voto Galicia en el año 1623, momento en que fue segregada de la circunscripción de Zamora, y posteriormente se volvería a ampliar la composición urbana con dos nuevos votos, uno para Palencia, que fue separada de Toro, y otro para Extremadura que se independizaría de Salamanca, con lo que el número de ciudades que tenían el derecho privilegiado de participación en las Cortes ascendió a veintiuno.

La otra reducción que padecieron las Cortes ante la autoridad de la Corona se produjo en el año 1538, cuando Carlos I decidió dejar de convocar para su participación en las reuniones a los representantes de los estamentos nobiliario y eclesiástico, quedando como únicos procuradores en Cortes a los representantes de las ciudades, quienes monopolizaron definitivamente esta asamblea. Los antecedentes de esta decisión se remontan a los comienzos del reinado de Carlos 1 , al evidenciarse el desinterés de los estamentos privilegiados por las Cortes, mientras que, por el contrario, si trataban de controlar el Consejo Real; ya en las Cortes de Valladolid de 1527 la nobleza había respondido a las peticiones de servicio que contribuirían con dinero y hombres si el Emperador participaba en una campaña militar, pero no por vía de Cortes, porque tal cosa parecería tributos y pechos que su nobleza y estado no lo permitiría; el clero, por su parte, manifestaba argumentos similares, y como consecuencia de estas actitudes Carlos I, al convocar las Cortes de Toledo en 1538, reunió por separado a los representantes de las ciudades y a la nobleza y clero (casi un centenar de nobles y más de treinta obispos), leyéndoles dos discursos distintos y negando a los estamentos privilegiados la condición de brazos de las Cortes, al afirmar que sólo eran brazos de las Cortes los procuradores de las ciudades, y poco después despediría a nobles y clérigos diciéndoles: viendo lo que se ha hecho, le parece que no hay que detenerse aquí VV.SS, 
sino que cada uno se vaya a su casa o donde por bien toviere, y de esta manera se concluyó el llamamiento que el Rey Carlos habia hecho a nobles y prelados, a los que ya nunca volvería a convocar a Cortes, decisión que también mantuvieron sus sucesores.

En la trayectoria institucional de las Cortes hay que recordar que en el año 1520 se había creado la Diputación del Reino, la cual fue configurada como un órgano reducido de las Cortes para su representación durante los períodos que se producian entre una y otra convocatoria, y también con el importante objetivo de controlar la ejecución de los servicios aprobados.

Fernádez Albaladejo señala cómo la renovación historiográfica que se ha producido en España sitúa en la primera mitad del siglo XV el momento crucial en la vida de las Cortes castellanas, pues la conocida inestabilidad política que siguió a la revolución Trastámara en el reino no permitió que en Castilla llegara a configurarse una asamblea interestamental y orgánica con capacidad suficiente para proceder, de manera conjunta con el Rey, a la elaboración de leyes; y, en acusado contraste con los reinos de la Corona de Aragón, el proceso de creación del derecho territorial no pudo producirse en Castilla a partir de la colaboración entre las Cortes y el Monarca; como consecuencia de esto la Corona fue estableciendo una normativa general para Castilla mediante el uso de las pragmáticas reales; y prosigue senalando el hecho de que las Cortes carecieran de facultades jurisdiccionales, y que desde el año 1445 se aceptase que formalmente el poder para dictar normas generales residía en el Monarca, todo ello, sin embargo, no permite emitir la conclusión de que el absolutismo hubiese tomado ya carta de naturaleza en Castilla, porque estaba generalmente admitido que la posición del Rey, en el ejercicio de sus facultades, habia que entenderla subordinada al Derecho Natural y con pleno respeto y aceptación de las soluciones contempladas por el Derecho común, haciéndose valer cómo en el Derecho Natural encontraban protección jurídica los derechos particulares a cuyo mantenimiento el Monarca estaba obligado ${ }^{1}$.

Junto a la reducción del número de ciudades que eran convocadas para participar en las reuniones de Cortes, se había producido también, en el año 1424, una limitación del número de representantes que enviaba cada concejo, el cual fue establecido en dos procuradores, y asi se mantuvo siempre, pues hasta ese momento los procuradores que representaban a los concejos podían ilegar hasta cuatro. Con todos estos acortamientos de la representación urbana, la Corona pretendía favorecer su control sobre las Cortes ${ }^{2}$.

'. P. Fernández Albaladejo: "Cortes y poder real: una perspectiva comparada», en VV.AA., Las Cortes de Castilla y León en la Edad Moderna. Valladolid, 1999, pgs. 492 a 499.

2. J. M. Carretero Zamora, Cortes, Monarquía, Ciudades. Las Cortes de Castilla a comienzos de la época moderna (1476-1515). Madrid, 1988, pgs. 3 a 9. 
Pero esta política restrictiva de la Corona era asumida por las propias ciudades con voto en Cortes, pues ellas concebian este privilegio como un derecho propio vinculado a su jurisdicción; para esos concejos estaban muy claros dos hechos: que tenian una representación propia que comprendía a la ciudad y su tierra, y que constituían la cabeza de una demarcación fiscal; pero sin que el privilegio recibido por la ciudad se extendiera a la provincia dependiente en su función tributaria. La desvinculación de la ciudad de voto respecto de los intereses y problemas de las ciudades y villas de su provincia era absoluta, y si en alguna ocasión presentaban a las Cortes alguna petición procedente de alguna de estas era, sencillamente, porque así aprovechaban el privilegio de audiencia en Cortes para reivindicar algún derecho que pudiera corresponderles ${ }^{3}$. Si las Cortes castellanas no eran asambleas legislativas, tampoco eran asambleas de representación territorial, pues las ciudades sólo hablaban por sí mismas.

Como hemos dicho, eran las necesidades financieras de la Hacienda Real las que originaban la mayor parte de las convocatorias de Cortes, a fin de que estas aprobaran el servicio necesario; por ello, la trayectoria de la institución estuvo muy influida por el devenir de la Hacienda Real, de tal modo que cuando al final del reinado de Felipe !l se produce la crisis financiera que se trataría de paliar con el Servicio de Millones, la consecución de este medio extraordinario para la Corona en las Cortes hizo rechinar los engranajes y estructuras de la institución, y, en ese pulso entre la Corona y las ciudades, estas consiguieron reducir en gran medida la influencia de la Corona sobre las Cortes, poniéndose de manifiesto con gran fuerza que las ciudades no estaban dispuestas a ninguna alteración que las perjudicase dentro del equilibrio de poderes establecido y del cual eran las principales beneficiarias, pues afirman que las decisiones sobre los problemas presentados a las Cortes por la Corona habían de habían de producirse en el seno de sus cabildos concejiles y no en una asamblea superior interpuesta, como ellos consideraban a las Cortes en ese momento; es decir, hacían de las Cortes un ámbito para establecer unas bases preliminares de negociación, pero la toma de las decisiones que dieran firmeza al acuerdo entre la Corona y el Reino se reservaba a las ciudades en sus concejos, y el procedimiento que instrumentaron para hacer efectivo este planteamiento radicó en una limitación del poder que los concejos otorgaban a sus procuradores en las Cortes, calificando al que estos recibían como voto consultivo mientras que el voto decisivo lo asumían los concejos, dando así a las ciudades en las Cortes todo el protagonismo político frente a la Corona. 
El avance de la Monarquía castellana hacia la posesión de un poder exclusivo y excluyente característico del Estado moderno, tuvo uno de sus componentes en la política de reducción y limitación de la participación del reino en las Cortes, que ya no eran una representación de la sociedad al desaparecer de ella dos de sus estamentos, el nobiliario y el eclesiástico, y con la exclusión de la nobleza se daba un paso más en el fortalecimiento del poder real, que desde los Reyes Católicos, y después con Carlos I y con Felipe II, tendrán a ese estamento marginado del ámbito político, como tal estamento; y también se avanza ligeramente en la secularización social con la exclusión del estamento eclesiástico. Por ello es ciertamente sintomática esta tendencia reductora que halla su conclusión no en un modelo de representación del reino semejante al de la estructura de la sociedad, sino que lo limita a los concejos de un restringido número de ciudades y villas, las cuales, por su parte, recibieron el privilegio de participación permanente en las Cortes y lo hacian con un talante de exclusividad, pues en las reuniones del año 1506 pedían al rey que no ampliara ese número, pues ello pondría en peligro los privilegios de que disfrutaban los regidores de los cabildos concejiles de las mismas, al constituir todos estos el reducido ámbito de elección a procuradores en las Cortes, y Pérez Prendes ${ }^{4}$ dice que "la ciudad, cuando reivindica el derecho exclusivo al voto no lo recaba para ejercitarlo frente al Rey sino frente al resto de las ciudades", lo cual no impide el avance del poder real en el ámbito político de Castilla.

Como consecuencia de la política real para restringir y limitar la participación en las Cortes de Castilla, al reducirla a dieciocho ciudades, podría pensarse que las Cortes se habían convertido en el foro donde se expresaba la voz de las ciudades, entendiendo como semejantes los términos "Cortes" y "ciudades", pero esto tampoco era así, pues las Cortes no tenían ningún carácter representativo, porque el voto en Cortes era considerado como un derecho exclusivo y patrimonializado por cada ciudad, que lo ejercia solidariamente contra las pretensiones de otras ciudades, no contra el Rey, como hemos visto afirma Pérez Prendes. No solamente estas ciudades no representaban a las demás ciudades y villas del reino castellano, sino que en el ejercicio de su participación en las Cortes prescindían por completo de las voluntades y opiniones de las ciudades y villas, o de las provincias las que cada ciudad de voto decía hablar.

En el año 1588, con la petición regia de un nuevo servicio, el de Millones, se abrió una nueva etapa en la historia institucional de las Cortes y, por consiguiente, en la historia de la relación entre Cortes y ciudades, apareciendo una nueva formula constitucional para manifestar la reformulación

‘. J. M. Pérez Prendes, "Cortes de Castilla y Cortes de Cádiz", Revista de Estudios Políticos, $n^{2}$ 126. Madrid, 1962, pgs. 382 y 383. 
del equilibrio político entre la Corona y las ciudades, la cual se expresaba de modo efectivo por la aplicación de los conceptos «voto decisivo" y "voto consultivo", donde el voto consultivo se exponía y ejercía en la reunión de Cortes, mientras que el decisivo pertenecía a los concejos de las ciudades de voto. Pero no por ello se abatieron las Cortes, al contrario, el nuevo régimen fiscal derivado del sistema de percepción de los Millones les otorgó un ámbito de actuación más amplio, tanto en las deliberaciones como en la administración del Servicio de Millones, y en este ejercicio de control llegaron a ser acusadas de usurpadoras de las atribuciones de los consejos reales, del de Hacienda especialmente, e incluso de la propia autoridad real con la efectiva subordinación de todas las ciudades castellanas a las ciudades de voto en Cortes, pues con motivo de la concesión del servicio de 17'5 millones de ducados en el año 1608, a petición de las Cortes, la Corona dictó una R. C. en la que se dice que «para que mejor se guarde todo lo que toca al bien y aumento de este servicio... (ordenamos) que todas las ciudades y villas destos reinos cumplan y obedezcan las Órdenes de las ciudades y villas de voto en Cortes en la que cada una ordenare en su provincia y distrito" " $;$ y es que el nuevo régimen fiscal organizado en torno a los Millones había permitido a las ciudades de voto en Cortes hacerse con una parte sustancial de la fiscalidad castellana, al establecer un control desde la Comisión de Millones y desde la red territorial por ellas constituida. Está comprobado cómo las oligarquías urbanas habían hecho de la renta de Millones la garantía para sus juros, por lo que si en el ámbito político habia un distanciamiento Cortes- ciudades, las necesidades financieras de la Hacienda real obligaban a mantener estable y firme esa relación, forzándose una identidad de intereses entre el rentismo urbano y la propia Monarquía ${ }^{6}$, y esto se plasmó de modo efectivo desde el año 1626 , cuando las Cortes se hicieron cargo de las nuevas emisiones de juros, quedando a cargo de la Corona la colocación del papel de estos títulos de la deuda pública y en su beneficio los ingresos obtenidos con su venta. A este respecto $M$. Artola, dice que la creación de una deuda de carácter permanente sobre una renta temporalmente limitada, como eran los servicios de Millones, obligó a introducir, en la escritura de formalización de estos, una cláusula por la cual las ciudades se comprometían al pago de los intereses de los nuevos juros para el caso de que no se renovase el servicio; se autorizó la enajenación de juros en cantidad tal que sus intereses no rebasaran los 500.000 ducados, siendo el tipo del $5 \%$, consignándose el pago de estos sobre la recaudación obtenida por medio de las cuatro sisas con las que se percibía efectivamente el servicio de Millones ?

5. Actas de las Cortes de Castilla, XXIV, fs. 699-700. Cita de A. Domínguez Ortiz, Crisis y decadencia de la España de los Austrias. Barcelona, 1984, pg. 103, nota 6.

6. Fernández Albaladejo, Fragmentos de Monarquía. Madrid, 1992, pag. 298.

'M. Artola, La Hacienda del Antiguo Régimen. Madrid, 1982, pgs. 146 y 147. 
Con la llegada al valimiento del Conde-duque de Olivares se produce una reacción contra la política practicada entre los años 1590 y 1620 , donde las ciudades habían conseguido una gran preeminencia frente a la autoridad real, intentándose en el reinado de Felipe IV, con la política de Olivares, recuperar la capacidad de maniobra de la Corona, restablecer su dirección en la administración de la Hacienda y asegurar la obediencia y colaboración del Reino; pero estos intentos fracasaron, lo que se trató de resolver mediante la restauración de unas Cortes independientes de las ciudades, y en la búsqueda de tal remedio se convocaron unas Cortes en el año 1632 para que el Reino jurase al infante Baltasar Carlos, pero con la importante novedad de que en la carta de convocatoria que se envió a las ciudades se incluía explícitamente la exigencia de que los concejos otorgasen a sus procuradores el poder decisivo; posteriormente, y ya durante el curso de esas reuniones de Cortes, Felipe IV, con una aseveración de sus derechos de regalía, y apoyándose en un dictamen de su consejo basado en la pervivencia y aplicación de las leyes de Alfonso XI y del Libro II de la Nueva Recopilación, declaró que el consentimiento de los procuradores sólo bastaba en derecho para otorgar servicios, sin dependencia ni confirmación de las ciudades, los procuradores, pues, debian presentarse con poderes de sus ciudades para "consentir, otorgar, hacer y concluir decisivamente todo lo que en dichas Cortes se propusiere, sin que sea necesario consultarlas en ninguna de las dichas materias" ${ }^{8}$. Con este planteamiento se pretendía que las Cortes de las ciudades se transformaran en Cortes de procuradores, consiguientemente los concejos de las ciudades de voto se reducirían a ser meros ejecutores de lo que en las Cortes de resolviese, y para ello los asuntos correspondientes al servicio real y al otorgamiento de servicios se deberían tratar con voto decisivo, los procuradores debería tener poder para ...consentir, otorgar, hacer y concluir por Cortes, sin depender del resultado de las consultas con sus ciudades. La respuesta de los concejos de las ciudades de voto a esta pretensión real fue la de una resistencia máxima para otorgar poderes decisivos a sus procuradores, pero la Corona no cedió y esta actitud se mantuvo hasta las últimas Cortes que se reunieron, las del año 1655.

La consecuencia de pasar el voto decisivo de las ciudades a las Cortes en el año 1632, fue dar forma legal a la separación institucional entre Cortes y ciudades; dar el voto decisivo a los procuradores fue individualizar los votos, desligándolos de una presunta representación comunitaria. Si en los años finales del sigic XVI se produjo el sometimiento de las Cortes a las ciudades, reduciéndose, o incluso perdiéndose la posibilidad de organizar de modo efectivo una representación de carácter nacional, al no poder fre-

\footnotetext{
8. I. I. A. Thompson, "Cortes y ciudades", en VV.AA., Las Cortes de Castillas y León en la Edad Moderna", ob. cit. pgs. 193 a 248.
} 
narse el avasallamiento que imponian las concepciones particularistas que impregnaban la política de los concejos, que no permitieron la evolución de las Cortes hacia una forma institucional que canalizase y expresase autorizadamente la voz de todo el reino castellano, cuestión que tampoco entraba en los objetivos reformistas que se estaban pretendiendo en 1632 , pues a esa altura de los tiempos los concejos estaban ya dominados por la oligarquía de los regidores perpetuos que patrimonializaban sus oficios desligados del común de sus vecinos en el gobierno local ${ }^{9}$.

El agravamiento progresivo de la situación financiera de la Hacienda Real hizo que por esa necesidad apremiante la Corona se aproximara a las ciudades, de tal modo que, al producirse la suspensión definitiva de la convocatoria de reuniones de Cortes, este hecho estaba ya asumido y aceptado implícitamente por las ciudades, y cuando en el año 1667 se proponga la prórroga del servicio de Millones, del conjunto de concejos correspondientes a las ciudades de Ávila, Burgos, Cáceres, Cuenca, Guadalajara, La Coruña, León, Madrid, Orense, Palencia, Salamanca, Soria, Valladolid y Zamora, solamente serán los de Guadalajara y La Coruña los que manifiesten su deseo de una convocatoria de Cortes. Este comportamiento de las ciudades tan favorable a los deseos de la Corona era consecuencia práctica de que la suspensión de las reuniones de Cortes había significado una restauración efectiva del voto decisivo en los concejos de esas ciudades y la resolución del problema de la relación Cortes-ciudades, tan crispado por su resistencia a perder la capacidad decisoria en 1632.

En cuanto al número de ciudades que gozaban del privilegio de participar en las Cortes, y a pesar del rechazo de estas para su ampliación, también serán las necesidades financieras de la Monarquía las que influyan para modificar esa situación, y asi Galicia, de la que constan desde el año 1520 sus peticiones para estar presente en las Cortes, consiguió en 1623 romper esas resistencias y negociar con la Hacienda Real la compra de ese privilegio mediante el pago de 100.000 ducados, segregándose este territorio de la circunscripción que correspondía a Zamora en su calidad de ciudad de voto, y ejerciendo el voto Galicia mediante la elección de sus procuradores entre los regidores de las siete ciudades gallegas.

Esta concesión real a Galicia fue muy mal asimilada por las otras ciudades con voto en Cortes, que al reunirse en el año 1626 manifestaron que no votarían la prórroga del servicio de Millones si se atendía alguna petición de las varias ciudades y regiones que aspiraban a sentarse en las Cortes, como eran Écija o Asturias. En las escrituras de las Cortes de

9. J. A. Ballesteros Diez: "Oligarquización de los concejos extremeños en el siglo XVIt", Boletín de la Real Academia de Extremadura de las letras y las artes, Tomo IX, Año 1998, pgs. 135 a 158. 
1638, vuelven los procuradores a imponer expresamente la condición de "que por los grandes inconvenientes que se siguen y han experimentado de que se acreciente el número de reinos y provincias que tienen voto en Cortes y los muchos gastos que se siguen dello, así a la Hacienda de S.M. como al Reino, se pone la condición de que en ningún tiempo se ha de poder dar voto en Cortes a ninguna ciudad, villa ni lugar destos reinos, ni se ha de acrecentar el número de votos que al presente ay con el de Galicia, ni que por esta condición adquiere ni se le atribuye derechos algunos a Galicia, sin perjuicio de la executoria del consejo" ${ }^{10}$. No obstante, frente a esta oposición, en el año 1650 se vuelven a vender dos nuevos votos en Cortes, uno para Extremadura, que se segregaba de Salamanca, teniendo que pagar a la Hacienda Real 80.000 ducados aportados por los concejos de Badajoz, Plasencia, Trujillo, Cáceres, Alcántara y Mérida, estableciendo que se turnarian de dos en dos para participar en las reuniones de Cortes, y otro para Palencia, que se separaba de Toro.

\section{LOS PROCURADORES EN LAS CORTES DE CASTILLA}

En esta aproximación a la evolución de las Cortes en relación al poder real y al protagonismo de las ciudades castellanas de voto en las mismas, hemos visto cómo, aquí también, se manifiesta el avance irrefrenable de las oligarquías urbanas en la conquista de ámbitos de poder, que en este de las Cortes consiguen tener en sus manos el control de la Hacienda Real y, además, garantizarse un buen rendimiento para sus inversiones en los juros, la deuda pública de aquel tiempo; lo que denotará, una vez más, el aspecto conservador de estas oligarquías. Por ello, antes de proseguir hacia el estudio de la compra del voto por Extremadura, parece necesario hacer un bosquejo del grupo social de los procuradores en las Cortes castellanas.

Como sabemos, desde las Cortes del año 1528 las ciudades eran en exclusiva las participantes, y en las reuniones eran representadas por algunos regidores de sus respectivos concejos. La elección de estos procuradores no se hacía con el mismo procedimiento en todos los concejos, y así Burgos era la única ciudad de voto en Cortes en la cual se elegían los procuradores mediante una votación secreta de todo su cabildo, lo que impedía la influencia directa de la Corona, o de cualquier otro poder, en la designación de determinadas personas para esa función, y ello confería a los procuradores burgaleses un cierto ascendiente sobre los demás, junto al hecho de que al ser Burgos la primera ciudad en el orden de prelación, sus opiniones y posturas siempre habian de ser especialmente estimadas.

10 J. L. Castellano, Las Cortes de Castilla y su Diputación. Madrid, 1990, pgs. 63 y 64. (La cita corresponde a las Escrituras de las Cortes de 1638, f. 66). 
En Sevilla, los veinticuatro elegían diez personas de su cabildo entre las cuales se sorteaban uno de los puestos de procurador en Cortes, mientras el cabildo de jurados hacía lo mismo para la otra procuración. En las ciudades de Ávila, León y Jaén, cada oficio de regidor servía la procuración de su turno en una rueda predeterminada. En otras siete ciudades: Toledo, Segovia, Murcia, Granada, Córdoba, Salamanca y Toro, el procedimiento que seguían para la designación consistía en echar a suerte la procuración entre los miembros de su cabildo respectivo, aunque en algunas de ellas se eliminaba de la insaculación a los regidores que ya la habían desempeñado hasta que todos ellos la hubieran servido. Por parte de otras cuatro ciudades: Madrid, Cuenca, Zamora y Guadalajara, el procedimiento para la designación era mixto, por una parte se elegía mediante sorteo entre todos los capitulares una de las plazas de procurador, $y$, por otra parte, del grupo de los caballeros parroquianos, o de los gremios nobles, se elegía al otro procurador, bien por sorteo o por una mezcla de suerte y nombramiento. En Valladolid, el concejo no tenía ninguna participación en la designación de los procuradores, pues los linajes nobiliarios de las familias Reoyo y Tovar tenían el privilegio de una procuración en Cortes cada uno, la cual se servía por turnos por el mayor de cada una de las cinco casas que componían cada linaje. Semejante era la situación en la ciudad de Soria, donde doce linajes presentaban a tres de sus miembros ante el concejo, para que se sorteasen las dos procuraciones y dejando al tercero de los presentados como sustituto de los elegidos, cumpliéndose así con el requisito legal de que la ciudad eligiese a sus procuradores, pues sin poder elegir a sus procuradores en Cortes las ciudades no podían determinar las capacidades políticas ni morales de sus representantes; y la insaculación existía precisamente para evitar sobornos, fraudes e incluso violencias a que daban lugar las elecciones en muchos lugares y en muchas ocasiones, pero a su vez tenía el inconveniente de que cualquiera de los regidores podía salir designado en el sorteo, fuese cual fuese su capacidad para el desempeño de esa función ${ }^{11}$.

Producida la elección, el concejo debía otorgar una carta de poder a sus procuradores, cuya redacción se iniciaba incorporando en su preámbulo la carta de llamamiento a Cortes y designando, con sus nombres y apellidos, a los procuradores elegidos; después se reproducian una serie de fórmulas habilitadoras de la función representativa: lugar y fecha de la reunión de Cortes, carácter de la representación y capacidad de gestión ( "...ver e platicar, e conferir e tratar todas e cualesquier cosas que en las dichas Cortes sus Altezas mandaren ver»); desde el año 1510 se habia homogeneizado este requisito , y para su cumplimentación se debian seguir las pautas establecidas por el "Memorial e instrucciones para la re-

1" I. I. A. Thompson, "Cortes y ciudades", ob. cit, pgs. 196 a 198. 
dacción de los poderes a los procuradores", del que había sido autor Miguel Pérez de Almazán, a la sazón Secretario Real.

La carta de poder, sobre cuyo alcance se basó en una gran medida la presión de los concejos frente a la Corona, contenía instrucciones muy concretas y detalladas, de las que los procuradores no se podian apartar, relativas a los asuntos propuestos por el Rey en la carta de convocatoria de las Cortes, y también en relación a las peticiones que, en nombre de sus ciudades, debian presentar al Monarca. Los procuradores recibian del concejo de su ciudad un mandato imperativo que debían observar estrictamente, hasta el punto de que si en las Cortes se trataban asuntos no previstos en la minuta que el Rey había enviado con la convocatoria, tenían la obligación de pedir a su concejo nuevos poderes e instrucciones. Esta limitación de los poderes fue tratada de salvar o, al menos, reducir, por los distintos monarcas desde los tiempos de los Reyes Católicos, pero el resultado había sido negativo, y con el paso del tiempo el enfrentamiento entre el Monarca y los distintos poderes representados en las Cortes se llegó a enconar, especialmente durante los reinados de Felipe III y Felipe IV, cuando los concejos hicieron un uso abusivo del voto consultivo, para defenderse mejor de la voracidad fiscal de la Corona, que exigía a los concejos que concedieran los poderes a procuradores con la calidad expresa del voto decisivo. Así pues, en oposición al inicial voto imperativo, el voto consultivo era el que pronunciaban los procuradores en las sesiones de Cortes, dejando el voto decisivo a sus concejos de procedencia; este hecho era criticado por Hernando de Ávila, cuando decía que «la limitación que las ciudades ponen a sus procuradores es expresamente contra la ley, porque debiendo enviar procuradores envían mensajeros o ministros, y aviéndo de darles poderes se los quitan", recordando $\mathrm{H}$. de Ávila cómo el Rey dio participación en el poder a los procuradores, no a las ciudades; y por tanto, el «derecho de otorgar las ciudades los nuevos impuestos no les compete a los cabildos, sino a los procuradores", quienes por "la naturaleza misma del mandato es poner el mandante o el señor en su mismo lugar el procurador y darle facultad para que el procurador haga, consienta y disponga como el señor de la cosa. Pues si a este procurador, aviendosele dado este poder, y este nombre, se le añadiese por condición que no avia de hazer nada sin nuevo consentimiento de su dueño ya dexava de ser procurador, porque se le quitava lo substancial, y pasava a ser mensagero, ministro o comisario, que ni uno ni otro tienen consentimiento en las acciones que se tratan por su mano... luego, aquella limitación que las ciudades les ponen a sus procuradores es expresamente contra la ley" ${ }^{12}$.

${ }^{12} \mathrm{H}$. De Ávila, Alegaciones sobre la materia de los votos consultivos. Sevilla, Año 1646, 1.3 (Citado por J. L. Castellano, Ob. cit, pag. 24). 
De entre los procedimientos para la designación de los procuradores en los concejos hemos visto cómo en algunas ciudades el nombramiento recaía en personas que no pertenecian al cabildo de regidores, recayendo en estos casos, generalmente, en miembros de ciertos linajes nobiliarios de las respectivas ciudades, lo que atestigua que, a través de situaciones privilegiadas, la nobleza seguía teniendo una representación en las Cortes, si no como estamento si por algunas personas que desempeñaban las procuraciones correspondientes a estas ciudades, los cuales abogaban decididamente por la preeminencia social y política de su estamento, pues reiteradamente se pedía por ellos en las Cortes que los regidores, veinticuatros y jurados de las dieciocho ciudades de voto fueran exclusivamente desempeñados por hidalgos de sangre ${ }^{13}$. Esta pretensión obedecía a dos objetivos, por un lado el afán corporativo de conseguir la exclusividad del gobierno en las ciudades de voto en Cortes, y por derivación también en estas; $y$ de otro lado, al estar los hidalgos exentos de tributos fiscales, no tener ninguna relación con las consecuencias sociales de la presión fiscal, pues habían llegado a tal gravedad las cosas que, durante el otoño del 1626, el Conde-Duque de Olivares hacía mención en una carta a la angustiosa situación a que habían sido reducidos los pecheros castellanos, diciendo así: "los que tenemos hacienda sabemos mejor atajar el rayo cuando nos amenaza que los pobres miserables del pueblo a quien condenamos siempre, porque los procuradores de Cortes y regidores que las han de votar echan su carga a la plebe miserable por no pagar ellos" ${ }^{14}$. Es difícil exponer con mayor claridad la ausencia de solidaridad de los procuradores en Cortes con el pueblo castellano, y para comprender mejor esta mentalidad y su consecuente comportamiento, veamos la procedencia social de lo procuradores en las Cortes del año 1615, en las cuales, de los 36 procuradores integrantes, 28 eran regidores concejiles, 1 era titular de un oficio asimilado al de regidor, 2 lo eran de otros oficios concejiles, y solamente 5 eran simplemente vecinos; pero esta vecindad no quiere decir que fueran del estado llano, pues en las Cortes del 1617 figuraban como vecinos los procuradores de Soria, que ya sabemos pertenecían a los linajes nobles de la ciudad; y si, además, recordamos que por esas fechas casi todos los oficios de regidores habían sido vendidos por la Hacienda Real concediéndoles la perpetuidad a sus propietarios, podemos progresar en la comprensión de cómo las oligarquías urbanas que controlaban los oficios concejiles eran las únicas que tenían acceso a las Cortes ${ }^{15}$.

13 A. Domínguez Ortiz, Instituciones y sociedad en la España de los Austrias. Barcelona, 1985, pag. 13 (nota 72); B. González Alonso, Sobre el Estado y la administración en la Corona de Castilla. Madrid, 1981, pag. 76.

${ }_{14}$ AGS. Est. Leg. 2043 (18-10-1629). Citado por J.H. Elliott, El Conde-duque de Olivares. Barcelona, 1990 , pag. 458.

${ }^{15} \mathrm{~F}$. Tomás y Valiente, La España de Felipe IV. (Tomo XXV de la Historia de España de Menendez Pidal). Madrid, 1982, pag. 181. 
La asistencia a las Cortes como procurador era una ocasión excepcionalmente propicia para ellos de conseguir favores y mercedes en su beneficio personal, hecho que denunciaría el propio presidente de las Cortes, Fernando de Acevedo, entre los años 1616 y 1622, cuando escribe que a los procuradores "nada les mueve sino el interés propio; en allanado este, todo es justo y sin dificultad, porque aunque más justa sea la necesidad del Rey, no mueve a estos tales sino el hábito, la encomienda, el oficio y el dinero que llevan de salario y ayuda de costas ${ }^{16}$, y así lo atestigua también Jerónimo de Barrionuevo, que decía: " a 27 procuradores de Cortes ha hecho S.M. grandes mercedes, $y$ a los otros 13 ninguna: son los de Murcia, Madrid, Salamanca, Toro, Valladolid, Zamora y otros, y todo esto ha pasado por mano de Don Juan de Góngora, a quien el reino dio de ayuda de costa 16.000 ducados, y de Peñaranda 6", y al publicar las mercedes el presidente de Castilla les dijo: “...tomen Vds. esas mercedes que les ha hecho S.M., que no aviendo sido generales a todos es 10 mismo que haberlas dado a cada uno un San Benito, y plegue a Dios que no los apedreen cuando vuelvan a sus ciudades..." ${ }^{17}$. Otro testimonio nos lo aporta Domínguez Ortiz, tomado de las Cortes del año 1660, cuando ante la petición de aumento de los tributos por parte de la Corona, el procurador de Sevilla, Ortiz de Melgarejo, exigió que antes de seguir debatiendo la concesión que pedía la Corona se diera certificación de todos los gastos de la Monarquía, incluyendo pensiones y ayudas de costa..., y era tan sorprendente el desusado lenguaje y el contenido de la intervención del procurador sevillano que Don Luis de Haro, sobrino de Olivares y sucesor de este en el valimiento, creía que Ortiz de Melgarejo adoptaba esa actitud exigente para conseguir con más facilidad mayores mercedes, por lo que el de Haro se las ofreció directamente y con el mayor cinismo, encontrándose con la sorpresa de tener ante sí a un procurador íntegro y sincero, que no buscaba el bien propio sino contribuir al bien de la Monarquia, por lo que el valido no sólo no le concedió beneficio alguno sino que anuló su procuración por una real cédula ${ }^{18}$.

Que los procuradores en Cortes no defendían los intereses del reino en su conjunto, sino los particulares de las oligarquías concejiles a las que pertenecian, era cosa que conocía perfectamente el gobierno de la Monarquía, y también los propios procuradores, que obraban buscando claramente la consecución de sus personales intereses y los de su cabildo concejil; por ello, cuando tras la muerte de Felipe IV, su viuda decidió que las 157.

${ }^{16}$ L. González Antón, Las Cortes en la España del Antiguo Régimen. Madrid, 1989, pgs. 153 a

17 I. De Barrionuevo, Avisos (1654-1658). Citado por F. Tomás y Valiente, La España de Felipe IV, ob. cit. pag.327,(nota 33).

${ }^{18}$ A. Domínguez Ortiz, La Sevilla del siglo XVII. Sevilla, 1984, pag. 106. 
Cortes ya no volvieran a reunirse, los componentes de estas, es decir, los regidores de los concejos de las ciudades de voto, prefirieron repartirse in situ los cargos para la administración del Servicio de Millones y no pelearse entre ellos para ir a las Cortes ${ }^{19}$.

Ante esta generalizada situación de egoísmo y particularismo por los grupos dirigentes de la sociedad castellana, Maravall cita a Carl Schmitt cuando este afirma que la lucha política es una lucha por la representación del todo, que los pequeños grupos oligárquicos que coparon los puestos de representación en las Cortes, cuyos intereses eran ajenos a todo sentimiento de unidad del pueblo como cuerpo político, no lo podían comprender ${ }^{20}$.

\section{LAS CORTES DE CASTILLA DURANTE EL SIGLO XVII}

Aunque en los epígrafes anteriores hemos avanzado algunos aspectos que caracterizaron notablemente a las Cortes en el curso de esa centuria, conviene encuadrarlos en un marco más amplio, porque en esa etapa se producen transformaciones trascendentes, especialmente en la relación entre Rey y reino en el seno de las mismas Cortes, y porque, en lo que respecta a nuestro trabajo, es el tiempo en el que se produce la incorporación de Extremadura a las Cortes de Castilla, y aunque la denominación de este derecho privilegiado sea el "voto de Extremadura" y este sólo se haga efectivo para los seis concejos extremeños que participan en su ejercicio, sin embargo, y ello es lo más notable, es la primera vez que en un órgano político del máximo nivel, dentro del ámbito del reino de Castilla, se manifiesta la voz de esta región, como tal región, a pesar de que en la terminología de aquel tiempo se la denominara "provincia de Extremadura", pero con la particularidad de que, junto a Galicia, eran las únicas provincias presentes en las Cortes que representaban a un territorio y no a una ciudad.

La petición por Felipe II del Servicio de Millones, en el año 1588, le obligó a conceder a las ciudades de voto en Cortes una serie de atribuciones que, hasta ese momento, se habían considerado inalcanzables y que radicaron en el hecho de que al haberse arbitrado que la percepción del Servicio de Millones se haría mediante una tributación a establecer sobre varios artículos de consumo, la ejecución, control, administración y liquidación a la Hacienda Real quedaba en manos de esas dieciocho ciudades, y aunque el nuevo servicio fue muy criticado por la pequeña nobleza urbana por considerarlo atentatorio a sus privilegios fiscales; sin embargo la adminis-

${ }^{19}$ F. Tomás y Valiente, La España de Felipe IV. Ob. cit. pag. 182.

${ }^{20} \mathrm{~J}$. A. Maravall, Estado moderno y mentalidad social. Siglos XV a XVII. Madrid, 1992, Tomo I, pgs. 361 a 363 . 
tración del Servicio de Millones fue muy bien recibida, y celosamente reivindicada, por las oligarquías concejiles, pues cuando palparon las posibilidades de maniobra que esta nueva atribución les abría la asumieron con carácter irrenunciable, y ello conduciria a que en la relación Monarquíaciudades, durante el siglo XVII, descansase la evolución constitucional del reino castellano ${ }^{21}$.

Las Cortes de Castilla, como institución representativa del reino, presentaba muchas y notorias imperfecciones que impedian se las pudiera calificar con tal carácter, y entre ellas hay que señalar cómo 36 procuradores, designados por 18 ciudades solamente, asumían la voz de todo el reino, con ausencia en esa representación de grandes regiones geográficas e históricas, tales como Galicia, Asturias y Extremadura. Si siempre habían defendido el exclusivismo de la representación por esas pocas ciudades, con la consecución de las nuevas atribuciones negociadas para otorgar el Servicio de Millones, se opusieron con la mayor fuerza a las pretensiones de participación en las Cortes de las ciudades y regiones excluidas, las cuales tenían el sentimiento de estar explotadas por las ciudades de voto, cabeza de su provincia respectiva, en el ejercicio de la administración fiscal de esas circunscripciones que el nuevo régimen tributario les había conferido, y ciertamente no les faltaban razones que abonaran dicho sentimiento.

Por otra parte, la estrechísima base social de la representación tenía la consecuencia de que las Cortes tuviesen un escaso apoyo popular, e incluso fuesen desconocidas en muchos pueblos castellanos, pues fuera de las ciudades de voto, o, más bien, fuera de los grupos oligárquicos de que procedian los regidores de esos concejos, no hay indicios de ningún eco de las disposiciones de las Cortes, y, menos aún, de apoyo popular hacia la institución ${ }^{22}$; pues no se puede olvidar que las Cortes eran una institución fundamentada en su origen sobre la base de la estructura estamental de la sociedad, y que aunque ahora sólo se halle teóricamente presente el estamento pechero, en la realidad había miembros de los tres estados. La sociedad se hacia presente en elias solamente a través de unos reducidos grupos oligárquicos, poseedores del poder en sus concejos, que defienden en las Cortes, ante todo, sus intereses particulares ${ }^{23}$, como hemos visto sucintamente, pero no hay planteamientos de ningún tipo relativos a la generalidad de cada estamento.

Con el reinado de Felipe IV y el acceso de Olivares al valimiento, se trata de enderezar y levantar el rumbo del gobierno de la Monarquia y corregir algunas situaciones en las que la relación de poder entre el Reino y

${ }^{21}$ P. Fernández Albaladejo, Fragmentos de Monarquia. Ob. cit. pags. 286 y 287.

22 I. I. A. Thompson, Cortes y ciudades. Ob. cit. pgs. 194 a 196.

${ }^{23}$ L. González Antón, Las Cortes en la España del Antiguo Régimen. Ob. cit. pag.160. 
la Corona se había desequilibrado excesivamente en favor de aquél, y así todo el reinado manifiesta continuamente el propósito de la Corona de recuperar su libertad de maniobra y asegurarse la obediencia del Reino, y entre esos intentos trató de eludir el dispensar con las Cortes y pasar directamente a las ciudades, como se hizo en octubre del año 1622, cuando se envió a las ciudades de voto las propuestas de la Corona para el establecimiento de los erarios y la financiación por los concejos locales de un reclutamiento de 30.000 soldados; tanto las propuestas como el sistema de tramitación empleado no prosperaron, porque una docena de ciudades exigía la convocatoria de la reunión de Cortes, usando esta petición como artimaña para frustrar los objetivos del programa reformista de Olivares. Posteriormente, en las Cortes del año 1629, que fueron las más largas de la historia de esa institución castellana, y en las que emparejada a su duración estuvo el nivel de dificultad que se oponía a las pretensiones de la Corona, pues los servicios votados por los procuradores fueron revocados, y en algunos casos reducidos, por los concejos de la ciudades al ejercer estos el voto decisivo y haber llevado, hasta sus últimas consecuencias, el desarrollo del procedimiento de concesión de voto consultivo a los procuradores, lo que llevó a la Hacienda Real a recurrir a la venta de vasallos, rentas, oficios e hidalguías. Tras esta dura experiencia, cuando en el año 1632 se vuelven a convocar Cortes, para que estas jurasen al infante Baltasar Carlos, en la carta convocatoria se exigió a los concejos que otorgasen a los procuradores el poder decisivo, y se hacía esto como una aseveración del derecho de regalia del Monarca; Felipe IV repudió la costumbre tolerada hasta entonces por ser una "gracia y dispensación tácita de los señores reyes", y declaró que el consentimiento de los procuradores sólo bastaba en derecho para otorgar los servicios sin dependencia ni necesidad de confirmación por las ciudades; con ello las Cortes se transformarían en Cortes de procuradores, y las ciudades quedarían como las ejecutoras de lo que en las Cortes se aprobase ${ }^{24}$. A la larga este golpe fue concluyente, a pesar del inmediato rechazo de las ciudades y de la renovación de su resistencia tras la caída de Olivares.

Durante el siglo XVII se produce una fuerte tensión entre dos concepciones distintas del poder, por una parte la que podríamos llamar pactista, encarnada por las ciudades, que pretendía compartir el poder con el Rey estableciendo que el Reino es también, parcialmente, poder, el cual se ejerce por las Cortes; $y$ de otro lado, la concepción autoritaria de la Monarquia, reforzada en cierta medida por el progreso del Estado moderno hacia el absolutismo, que atribuía al rey el poder supremo y decisorio, incluyendo en este poder la capacidad legislativa plena, de la que carecen las Cortes; pero lo que no se aceptaba era la potestad del Rey para impo-

24 I. I. A. THOMPSON, “Cortes y ciudades". Ob. cit., pgs.215 a 221 . 
ner tributos, a la que se oponían tanto las Cortes de los diversos reinos de la Monarquía como los teólogos y tratadistas políticos, pues la necesidad de que las Cortes participasen e interviniesen en la aprobación de los servicios se consideraba como una de sus iniciales y fundamentales razones para justificar su propia existencia como institución ${ }^{25}$.

Esta lucha que se padece durante el siglo XVII en ese ámbito político, hace plantear a Tomás y Valiente la pregunta de que si la resistencia ejercida contra el absolutismo real, utilizando como trincheras la constitución jurídico-política de los reinos y mentalidad o conciencia de una identidad propia por las naciones respectivas, ¿no serian batallas reñidas y ganadas por los estamentos dominantes en cada una de ellas?. Vemos claramente que sí, pero matizamos que no pensamos que fueron triunfadores los estamentos, como tales grupos sociales, sino las oligarquias de los poderosos que al pertenecer a estamentos distintos ya anticipan una disolución de la estructura estamental de la sociedad que caracterizaba el Antiguo Régimen y emergen unos grupos sociales nuevos en la disputa por el poder; $y$ prosigue Tomás y Valiente con'su análisis enunciando, en un claro diagnóstico de lo que estamos viendo, que esos estamentos oscilaron entre una política consistente en resistir al Estado absoluto haciéndose fuertes en los privilegios estamentales y en las constituciones de los reinos, caso de Cataluña; y otro modelo de política, que él define como de participación interior, en la que no se ofrecerá resistencia al Estado desde fuera sino que se tratará de controlarlo desde dentro, ocupando para ello los puestos claves de las instituciones de gobierno de la Monarquia, y es lo que vemos sucedió en Castilla ${ }^{26}$, como ya antes se había producido en los ámbitos locales de los concejos castellanos.

Pero dentro de ese ambiente de enfrentamientos dialécticos, políticos, e incluso militares, que padece la Monarquía durante el reinado de Felipe IV, en opinión de algunos tratadistas, también se produce una cierta modernización de la representación en Cortes, y la sostienen en tres hechos fundamentales: primero, la desaparición legal del mandato imperativo, en el año 1632; el segundo consistió en los intentos desde el gobierno de la Monarquia para aislar e independizar a los procuradores de cualquier influencia o manejo por parte de su entorno, y para ello se prohibió la venta y transferencia del cargo de procurador en Cortes, aunque hubo excepciones frecuentes; $y$ el tercer hecho, del que se benefició Extremadura, fue la ampliación del número de ciudades con el privilegio de estar representadas en las Cortes de Castilla ${ }^{27}$.

${ }^{25} \mathrm{~F}$. Tomás y Valiente, La España de Felipe IV. Ob. cit., pag. 100.

${ }^{26} \mathrm{~F}$. Tomás y Valiente, La España de Felipe IV. Ob. cit., pgs.65 y 66.

${ }^{27}$ J. L. Castellano, Las Cortes de Castilla y su Diputación. Ob. cit., pgs. 63 y 64. 
Con el final del reinado de Felipe IV se produjo un hecho singular en la historia de las Cortes castellanas. El día 31 de agosto de 1665, el rey convocó a las ciudades privilegiadas para que se reunieran en Cortes en Madrid el día 15 de octubre siguiente, con el fin de que prestasen juramento al príncipe Carlos como heredero de la Corona, y también para "entender en otras cosas y negocios de importancia que se ofrezcan tratar de mi servicio y conservación y defensa desta Corona»; pocos días después, el 14 de septiembre, Felipe IV otorgaba testamento y en él designaba a la reina Doña Mariana como gobernadora de la Monarquía; el 17 de septiembre se produjo la muerte del rey. Tres días después la reina-gobernadora se dirige a las ciudades de voto en Cortes del siguiente modo: "Habiendo acordado el Rey mi señor que está en gloria se juntasen Cortes Generales destos reinos para jurar al Rey Don Carlos Segundo, mi hijo, como a Príncipe primogénito y heredero dellos, por su carta patente de 31 de agosto pasado deste año, os envió a mandar eligiesedes vuestros procuradores y les diesedes poder bastante para ello y otras cosas que se ofrecieren tratar en su servicio y conservación desta Corona y que se hallasen en mi Corte para el 15 de octubre que viene, y porque Nuestro Señor a sido servido de llevarse para sí a S. M. y quedando mi hijo por heredero y subcesor universal de todos sus reinos y señoríos, con que ha cesado la causa para la que se mando convocarlas y no es necesaria esta función, sino sólo la de alzarse los pendones en la forma que se acostumbra y lo tengo mandado; he resuelto se excusen las Cortes y se cese en la disposición dellas; $y$ asi os mando sobreseais en la exención de la dicha carta-convocatoria para que no se pase adelante en cosa alguna tocante a ellas, que así es mi voluntad". La única razón que da la reina Doña Mariana para suspender la convocatoria de las Cortes es que al morir el rey Felipe IV el príncipe pasa automáticamente a ser titular de la Corona, como Carlos II, y, en consecuencia, ya no debe ser jurado como príncipe heredero, sino simplemente ser aclamado como Rey ${ }^{28}$.

Está claro para los historiadores que había otras razones, además de la argumentada por la reina, para motivar la suspensión de las Cortes, y así opina Sabater que Doña Mariana y su junta consultiva tenian los ojos fijos en la revolución inglesa, habían visto la negativa de las Cámaras a votar los subsidios y comparaban el carácter de aquellos tribunales con el que se desplegaba en España por Don Juan José de Austria, el hijo bastardo de Felipe IV, y estremecidos ante el cadalso de Strafort y Carlos I, siguieron el movimiento absolutista que estos desmanes justificaban y rehusaron convocar unas Cortes que se habían convertido en Inglaterra en un tribunal de muerte para sus reyes ${ }^{29}$. Para otros historiadores, la razón que movía efec-

${ }^{28}$ J. L. Castellano, Las Cortes de Castilla y su Diputación. Ob. cit., pgs. 70 y 71.

${ }^{29}$ P. Sabater, "Carlos II. Causa porque dejaron de reunirse las Cortes en su reinado", Revista de Madrid, II, Año 1839, pag. 551. (Cita de J. L. Casteliano, Ob. cit., pag. 77) 
tivamente a suspender la convocatoria de Cortes era la de impedir que, a través de las mismas, pudiera manifestarse la oposición del Reino por causa de que no se estaban respetando en todos sus puntos las disposiciones testamentarias de Felipe IV.

Durante el reinado de Carlos II se estableció como práctica la consulta a cada ciudad con voto en Cortes para conseguir la aprobación directa por su cabildo concejil, marginándose de esta manera la necesidad tanto de procuradores como de las mismas Cortes, y así sucedió en julio de 1667, cuando se comunicó a las ciudades que el Servicio de Millones iba a terminar en 1668 y se pedía una renovación del mismo por un período de seis años; $y$ este mismo procedimiento se siguió en el año 1673 al agotarse el Servicio de Millones que se había renovado en 1668.

Con el cese de las convocatorias de Cortes tomó un mayor protagonismo la Diputación del Reino, que había sido creada por Carlos I, en el año 1525, como institución destinada a velar por el cumplimiento de los acuerdos de Cortes. En su trayectoria hay que señalar que, en 1536, la Diputación se hizo cargo de la administración del encabezamiento general de las alcabalas, que de ser un acuerdo de tipo fiscal pasó a ser un instrumento político cuando en el 1538, por la falta de ayuda que le prestaba el estamento nobiliario al rey, este resolvió que para participar en las Cortes de Castilla sólo fuesen convocadas las ciudades, y ya con estas se comprometió a la congelación del encabezamierito de las alcabalas por un período de diez años, que luego llegaron a ser veinticuatro, a cambio de la renovación durante ese tiempo del servicio con algunos incrementos. Cuando en el año 1588 se presentó en las Cortes la petición del nuevo Servicio de Millones, estas rechazaron hacer un encabezamiento como el que se había realizado con las alcabalas, por lo que fue preciso efectuar un repartimiento por mayor, procedimiento con en el que se determinaba la cuota correspondiente a cada una de las dieciocho provincias, o circunscripciones fiscales, dependientes de las ciudades de voto en Cortes; y este repartimiento por mayor tenía que ser acompañado, necesariamente, por otro repartimiento por menor en el que se detallaba la cuota a percibir en cada partido, y dentro de estos las correspondientes a cada una de las ciudades, villas y lugares ubicadas en el mismo; advirtiéndose que se tuviera en cuenta la circunstancia muy frecuente de que la nobleza estaba preferentemente en las ciudades pero tenían buena parte de su riqueza y patrimonio en las aldeas, y también por esta debían tributar, y es que el nuevo Servicio de Millones suponía pasar de la tributación indirecta de las alcabalas a una tributación directa y general, pues Felipe II se mantuvo inflexible en la inciusión de nobles y eclesiásticos para contribuir en este nuevo servicio, cuya cobranza y administración habia de ser controlada por la Comisión de Millones, nueva institución derivada de las Cortes que empezó a funcionar paralelamente a la Diputación del Reino. 
La representación del reino, en ausencia de las Cortes, en el hueco de Cortes, según la expresión de la época, quedaba en la Comisión de Millones y en la Diputación del Reino, aunque realmente esta representación compartida solamente se manifestaba en los actos protocolarios, pues de hecho la representación de las Cortes la ejercía la Diputación: mientras que la Comisión de Millones tenía por principal cometido la administración y cobranza de los Servicios de Millones, como ya hemos dicho, y cuya prórroga la conseguía la Corona con cierta facilidad, mediante la presión a los regidores de las distintas ciudades de voto por sus respectivos corregidores, y, por otra parte, concediendo mercedes a aquellos procuradores que más secundaban la política real.

Por su parte, el normal desenvolvimiento de la Comisión de Millones sólo se alteraba por los cambios derivados de la intervención de las distintas ciudades de voto a raíz del cese de las convocatorias de Cortes; la práctica normal había sido que, una vez votado el Servicio de Millones, se procediese a cubrir por sorteo entre todos los procuradores los puestos de Comisarios de Millones, que a la sazón eran cuatro, como titulares o propietarios, y otros tantos como suplentes. Con la interrupción de la convocatorias de Cortes, y también la de su correspondiente reunión, desaparecía el ámbito de designación de estos comisarios y aparecía el problema de determinar entre quiénes se habían de sortear los cargos de la Comisión de Millones. Como solución inmediata se decidió hacer vitalicios en su desempeño a los comisarios nombrados en las Cortes del año 1664, pero conforme fueron desapareciendo estos comisarios, por fallecimiento o por haber conseguido otro empleo mejor, fue necesario buscar el reemplazo de los mismos, y se arbitró para ello como procedimiento que esas vacantes se cubriesen por sorteo entre los procuradores que aun quedaban de las Cortes de 1664, por lo que la Diputación escribió a las ciudades, en el año 1679 , diciendo que "para que las ciudades donde hubiese caballeros procuradores de Cortes de las que se disolvieron en 14 de noviembre de 1664 den aviso a la Diputación del Reino, y no le aviendo sorteen cada una dos caballeros regidores y remitan testimonio de a quienes a tocado para que entren en la que la Diputación destos reinos a de echar"; igual procedimiento se apiicó en el año 1687 , pero en el 1690 se produjo la novedad de que varias ciudades pidieron "que cada sexenio en que se prorrogasen estos servicios por las ciudades corra la regla como si estuviese en Reino en Cortes; para en cuanto a la administración y nombramiento de sus comisarios entre sus capitulares por suertes como ocurría con los procuradores", y en apoyo de esta propuesta, que suponía la anulación del carácter vitalicio que se había dado a los comisarios de Millones, se alinearon la mayoría de las ciudades, y entre ellas Mérida y Trujilio, que eran las que en ese momento representaban a Extremadura, y no consiguieron hasta el año 
1694 el acuerdo del rey a esta propuesta ${ }^{30}$; todavía, en el año 1698 , los regidores de Plasencia y Alcántara seguían sin haber conseguido participar en las Cortes, ni en la Diputación, pues había tenido la mala fortuna de quedar los últimos en el turno establecido cuando se compró el voto en Cortes, y por ello pedian se les autorizase a entrar en la Comisión de Millones ${ }^{31}$.

Por otra parte, con el cese de las convocatorias de Cortes, se inició también el último tramo de la Diputación en su andadura histórica. Desde siempre las ciudades se habían turnado en la designación de los procuradores que habian de participar en la Diputación durante el hueco de Cortes, pero al no producirse la reunión de estas las ciudades se veían lesionadas en el uso y disfrute de sus derechos y privilegios, lo que dio lugar a un largo conflicto al que no se halló solución hasta el año 1694, cuando por una R. C. se decretó la supresión de la Diputación, a la vez que se ordenaba el traspaso de sus funciones a la Comisión de Millones, estableciéndose una normativa para efectuar los nombramientos de los que, a partir de ese momento, serían llamados "Procuradores Comisarios de Millones" ${ }^{32}$.

Para Castellano, la razón que determinaba el interés de las ciudades, 0 , mejor dicho, de los regidores de sus concejos, para entrar a formar parte de la Comisión de Millones, era la posibilidad de manejar en sus circunscripciones la percepción y administración del Servicio de Millones, porque a la Comisión correspondía administrar todas las sisas y otros medios elegidos por el Reino para la satisfacción del Servicio, así como entender en el gobierno y cobranza de los mismos, proponer los administradores generales que se podian elegir para las provincias y, también, los particulares que les pareciere poner en las cabezas de partido ${ }^{33}$. Es decir, gozaban de una capacidad de manejo en asuntos de dinero verdaderamente extraordinaria, y con ello acrecentaban su poder de una manera efectiva.

\section{LA REUNIÓN DE LAS CORTES DE CASTILLA DEL AÑO 1650}

En 1638, los procuradores habían conseguido imponer la condición al Rey de que no se acrecertase el número de ciudades con voto en Cortes, pero las necesidades financieras de la Hacienda Real durante el reinado de Felipe IV eran acuciantes, y más aun con los cuantiosos gastos militares que se produjeron con las secesiones de Cataluña y Portugal, por lo que

${ }^{30}$ J. L. Castellano, Ob. cit., pgs. 85 a 90.

${ }^{31}$ A. H. N., Consejos, 7178, num. 3 (Documento citado por A. DOMÍNGUEZ ORTIZ: Crisis y decadencia en la España de los Austrias. Ob. cit., pag. 111, nota 22).

${ }^{32}$ J. I. Fortea Pérez, "Trayectoria de la Diputación de las Cortes", en VV. AA., Las Cortes de Castilla y León en la Edad Moderna, Ob. cit., pag. 41.

${ }^{33}$ J. L. Castellano, Ob. cit., pgs. 92 y 93. 
en las Cortes de $1650^{34}$ el rey propuso, el día 20 de noviembre, que se le autorizase a imponer el tercer $1 \%$ sobre todo lo vendible, por un plazo de seis años; que las Cortes aceptasen la venta de procuraciones a Cortes para cinco ciudades; y como tercer medio, acrecentar y vender un regimiento en los concejos de todas las ciudades, villas y lugares del reino; derogando necesariamente los privilegios que muchas ciudades habían comprado para que no se volvieran a acrecentar sus cabildos concejiles.

Los procuradores asistentes a estas reuniones de Cortes, eran los siguientes:

\begin{tabular}{|c|c|}
\hline Procurador & Ciudad de Voto \\
\hline $\begin{array}{l}\text { Don Juan de Cañas } \\
\text { Don Francisco de Salamanca } \\
\text { Don Diego de Salvatierra } \\
\text { Don Alonso de la Serna } \\
\text { Don Joseph de La Calle } \\
\text { Don Luis de Montesinos } \\
\text { Don Francisco de Laredo } \\
\text { Don Francisco de Valdés } \\
\text { Don Diego de los Rios } \\
\text { Don Martín de Guzmán } \\
\text { Don Francisco Galtero } \\
\text { Don Juan Fernández de Alarcón } \\
\text { Don Francisco Martín de Avilés } \\
\text { Don Gaspar Antolín de la Serna } \\
\text { Don Francisco de Salcedo } \\
\text { Don Diego Gutierrez de Montalvo } \\
\text { Don Mateo de Valdés } \\
\text { Don Julián Árias } \\
\text { Don Joseph Crema } \\
\text { Capitán Juan de Segovia } \\
\text { Don Diego Vázquez de Aldama } \\
\text { Don Diego Ordónez } \\
\text { Don Manuel Henrriquez } \\
\text { Don Antonio Pacheco Triviño } \\
\text { Don Antonio Vela de Tapia } \\
\text { Don Antonio del Hierro } \\
\text { Don Melchor de la Bastida } \\
\text { Don Francisco Arévalo de Zuazo } \\
\text { Vizconde de Laguna } \\
\text { Don Antonio (Juan) Pinar } \\
\text { Don Gerónimo Hurtado } \\
\text { Conde de Altamira Burgos }\end{array}$ & $\begin{array}{l}\text { Burgos } \\
\text { Burgos } \\
\text { Salamanca } \\
\text { León } \\
\text { Granada } \\
\text { Granada } \\
\text { Sevilla } \\
\text { Sevilla } \\
\text { Córdoba } \\
\text { Córdoba } \\
\text { Murcia } \\
\text { Murcia } \\
\text { Jaén } \\
\text { Jaén } \\
\text { Soria } \\
\text { Soria } \\
\text { Cuenca } \\
\text { Cuenca } \\
\text { Valladolid } \\
\text { Valladolid } \\
\text { Toro } \\
\text { Zamora } \\
\text { Zamora } \\
\text { Ávila } \\
\text { Ávila } \\
\text { Guadalaraja } \\
\text { Guadálaraja } \\
\text { Segovia } \\
\text { Segovia } \\
\text { Toledo } \\
\text { Toledo } \\
\text { Galicia }\end{array}$ \\
\hline
\end{tabular}

${ }^{34}$ Actas de las Cortes de Castilla. Tomo LVIII, Vol I (Cortes de Madrid de 1650 a 1651, de donde procede toda la información que sigue). 
En la reunión del día 10 de diciembre se produce la primera votación sobre los medios pedidos por el Rey y el consiguiente debate entre los procuradores, con el resultado final de que se rechazaron los tres medios propuestos, únicamente dieron su voto favorable a la petición del monarca, el conde de Altamira, Don Antonio Vela de Tapia, el vizconde de Laguna, el cual acepta y expresamente dice que daba su consentimiento para S. M. vendiera dos procuraciones de Cortes, una para Andalucía y otra para Extremadura; todos ellos manifestaron que seguian los argumentos expuestos por el conde de Hernán Núñez, procurador por Córdoba, quien había dicho "que considerando la extrema cortedad con que la Hacienda Real se halla y los grandes empeños en que $S$. M. está justamente de sustentar tantos exercitos que le an obligado a ordenar a sus ministros le consulten los medios mas suabes y menos sensibles que se puedan hallar para que el Reyno le sirva, continuando la fineza y amor con que siempre lo a hecho, $y$ que no se an hallado otros en quien se puedan considerar menores inconvinientes que los que S. M. se a servido de proponer al Reyno, es por su voto en dispensar por esta vez la condición de millones que prohíbe no pueda S. M. vender oficio de Regidores para que pueda vender uno en cada lugar, y de la misma suerte es dispensar la condición de dichos millones que prohíbe no puede S. M. llamar a Cortes más ciudades que las que oy se hallan juntas, para que S. M. pueda llamar otras cinco ciudades mas, con calidad que la cantidad con que las dichas ciudades sirvieren a $S$. $M$. por esta merced, S. M. no les de facultad para cargarla sobre las quatro especies de que se paga el sevicio de los veinte y quatro millones; assimismo es en conceder a S. M. uno por ciento en extensión de la alcavala por tres años como corren los otros dos por ciento que el Reyno a concedido a S. M. de esta calidad, y a de ser condición de este servicio que S. M. se a de servir de concederla antes de aceptarle que se guarde la condición segunda del primer género del servicio de los veinte y quatro millones que dispone no aia de dar S. M. facultad a ninguna ziudad ni villa de estos reynos para que puedan cargar para ningún effecto maravedís ninguno sobre las quatro especies, sino que estas queden libres sin otra carga ninguna mas del que el Reyno tiene concedido sobre ellas para la paga del servicio de los veinte y quatro millones y ocho mil sodados y lo que corre con este servicio, y que todas las facultades que estubieren dadas se an de anular $y$ mandar que corran de suerte que estos géneros queden libre solo con la carga referida y con esta condicion, y que $S$. M. se sirva de mandar en todos los Consejos, juntas y tribunales de estos Reynos que sus ministros no puedan llebar propinas ni luminarias porque es materia de que resultan grabes inconvinientes a estos Reynos, y para reconocer la justificación de esta condición puede S. M. servirse de mandar se le de razón de los efectos de que se cobra este género de emolumentos".

El día 16 de diciembre, los procuradores redactan una consulta al Rey, con el tenor siguiente: "Señor: Habiendo visto el Reyno una orden de V. M. 
remitida por el Presidente del Consejo en que manda se le conceda tercero uno por ciento por seis años y se preste consentimiento para la venta de cinco procuraciones de Cortes, y un Regimiento en todas las ciudades, villas y lugares de estos Reynos, desseando con su acostumbrado amor y fineza que en los medios referidos se hallaren las conveniencias que se deben considerar para el mayor acierto en el servicio de V. M. con el menor gravamen de sus vassallos, procura con todo desvelo conferirlo y por 10 discurrido en la materia se le ofrece repressentar a V. M. lo siguiente:

Que la principal caussa de hallarse estos Reynos en tan miserable estado a sido la multiplicación de medios que se an impuesto cargando los que hasta aqui an corrido en los pobres y necessitados, y siendo mas 10 que an padecido por la diversidad de contribuciones que por la naturaleza de ellas mismas.

Que la experiencia a señalado que el multiplicar los impuestos es caussa de que se minore el valor de los que estan assentados, como se reconoce en las sisas de las quatro especies, pues por averseles acrecentado el sueldo de los ocho mil soldados, las quiebras y otros medios particulares an venido a tan grade disminucion que oy se reputa por unico remedio para que buelban a su antiguo valor el reducillas a su primitivo estado, $y$ esto mismo se a experimentado en el uno por ciento, pues en algunos lugares produjo tanto el primero solo como después de haberse doblado y lo que a frutificado faltó de las alcavalas como se a visto en las grandes vajas y quiebras que an tenido después que se a introducido esta contribucion, assi por los fraudes que ressultan de la ganancia que de ella se sigue como por aver cessado la maior parte de los tratos y comercios que tanto ymportan a la conservacion de los Reynos por ser los derechos tan subidos, con que an crecido sin limite los precios de los mantenimientos y demas cossas necessarias para la vida humana.

Que estos inconvinientes y otros experimentados en todos los servicios se hallan precissos en el tercero uno por ciento por ser tan general que comprehende todas las cossas desde la maior a la menor, con que todo lo que rindiere a de vajar delos demas servicios, gravando de nuebo a los pobres labradores, que son los que viben de vender y comprar sus frutos, y esta es la caussa de que sientan tanto este genero de impossicion.

Que ay pocas ciudades en Castilla y Andalucia que no esten deviendo a V. M. grades sumas de los servicios que oy corren, y siendo esto así, mal podra comprar voto en Cortes, que es el segundo medio, y pagar tanta cantidad como la en que se estima quien no puede satisfascer lo que debe, y lo que por esta razon se offreciere se habra de cargar en las sissas o en las mismas contribuciones de que oy se ussa, pues a haber otras nuebas ya se hubieran elegido para el servicio de S. M. o para situar las quiebras, o para el remedio de otras necessidades que padecen los pueblos, que 
son tantas que no es possible se halle arvitrio de que en tanto discurso de tiempo no se avian valido, y assi todo lo que rindiese este medio vajara de los demas de la misma suerte que queda dicho en el passado, y solo servira de que crezcan los travajos de los vassallos, sin redimir la necesidad de $V$. M. por no ser tampoco este effecto tan pronpto como piden las ocassiones presentes, y redundara solo en util de aquello a quien tocare la suerte de Cortes $y$ en ellas bien se reconoce quanto gasto ocassionara $a \mathrm{~V}$. M. y quanta confussion a esta comunidad, que sobre el numero de treinta y ocho capitulares se añadan diez dificultando y aun impossibilitando el expediente de las materias, opuesto todo al servicio de $S$. $M$. por las razones referidas $y$ otras muchas que se excussan por la proligidad bien previstas $y$ prevenidas por los señores Reyes predecessores de V. M. cuando dispusieron las Cortes en la forma que oy estan.

Que en quanto al tercer medio no parece parte el Reyno para derogar los privilegios comprados por las ciudades y villas por grades cantidades y son tantas las que lo tienen de que no se les puede añadir regimiento, que las que restan ademas de ser pocas son las de menos posible y donde valen poco los officios, de que no se puede esperar fruto considerable, $y$ solo servira de ocasionar en los lugares nuevas dissensiones $y$ penalidades.

$Y$ assi, en consideración de los inconvenientes referidos y otros muchos que se dejan a la prudentissima y piadosissima poderacion de $V$. M. con sumo dolor y sentimiento de que lo que proponemos no parezca de su real servicio para el socorro de tantas necessidades como se ofrecen y de que compitan igualmente en $\mathrm{V}$. M. la realidad de su clementissimo animo en solicitar el alivio de sus vassallos, y en ellos la debilidad de sus postradas fuerzas para hacer las demostraciones devidas a su real clemencia se halla el Reyno obligado a representar a $V$. M. las razones que se le ofrecen para supplicarle se sirva de mandar no se usse de estos medios y postrado con toda humildad y reverencia a sus reales pies pone a ellos unos muy rendidos deseos de hallar otros que sean mas effectivos y demas util al servicio de V. M. y menos gravosos para sus vassallos en cuio examen se desvelara incessantemente, continuando el amor y fineza con que se a servido a $V$. $M$. en tantas ocasiones como se an offrecido en estas Cortes prometiendose que por este camino mediante el sancto celo de $V$. M. se an de continuar en esta monarquia los buenos subcesos que oy se experimentan y que a de dar Dios a $V$. M. para bien unibersal de estos reinos en propagada subcesion, colmadas prosperidades y para admiración de los extraños a sus catholicas armas en repetidas victorias, gloriosos triunphos y muy felices progressos. de que da quenta $V$. M. que mandara lo que mas fuere servido. Madrid, dieciseis de diciembre de 1650"

Cita Domínguez Ortiz que en la copia de ese documento un anónimo había añadido estas líneas: "Por esta consulta se enfadó S. M. y mandó di- 
solver las Cortes. Entraron ministros a mediar y se prorrogaron, y concedieron al Rey la venta de dos procuraciones de Cortes a dos ciudades, y un millón repartido en todos los que tienen oficio real. Así se executó y a mi como regidor de Salamanca me tocaron treinta ducados que pagué al año 1.651" ${ }^{35}$.

Al seguir el texto de las Actas, vemos que, en la sesión del día 18 de diciembre, el Presidente del Consejo leyó a los procuradores un papel del Rey que decía:

«S. M. que Dios guarde, llamó a Cortes a V. S. por instar tanto los aprietos y necesidades publicas de acudir a la defensa de la Religión Católica y destos Reynos, de que se dió quenta a las ciudades en las convocatorias, y repetidamente a V. S. en espacio de cassi dos años que están juntas las Cortes, y siendo ia tiempo por muchas razones de disolverlas y de que $V$. Señorías se buelban a sus cassas, me a mandado $S$. M. se lo diga assi a V. S. para que 10 executen, concluiendo las materias que estubieren pendientes de aqui al viernes a las diez horas de la mañana que se contarán veinte y tres de este mes de diziembre. Nuestro Señor guarde a V. S. como desseo. Madrid, diecisiete de diziembre de 1650. Lizenciado don Diego de Riaño y Gamboa".

Prosiguen los debates sobre diversos asuntos, y el dia 21 de diciembre se informa que "los caballeros comissarios nombrados para hablar al ilustrissimo señor Presidente del Consejo y señores assistentes de Cortes y darles quenta como el Reyno estaba buscando medios para servir a S. M. Io dieron de haberlos hallado, y que el señor Presidente respondió en nombre de S. M. que estaba con toda estimación de la fineza y voluntad que el Reyno mostraba de servirle y que siempre había creido lo mismo de Junta tan grande, donde concurren caballeros de tantas partes como en este Reyno se hallan, y assi le parecia muy bien, y se conforma con que se voten oy los dos medios del regimiento en todas las ciudades y villas destos Reynos y de las procuraciones de Cortes y el servicio a S. M. con un millón de ducados para la campaña que viene en la conformidad de que el Reyno lo había repressentado todo y sobre los medios que al Reyno le pareciesse que incluian las partes que S. M. desea y a menester de efectivos para este año y con el mayor alivio y menor daño que se puede de sus vassallos y por que aora no se ofrecian medios al Consejo que proponer al Reyno".

Acto seguido los procuradores debatieron sobre la propuesta de servir con un millón de ducados que precisaba la financiación de la campaña militar que se avecinaba, para que lo pagarar las personas que disfrutaban de un oficio público, aprobándose la proposición expuesta por el conde de Altamira, que aceptaba la cuantía de ese servicio por un millón de ducados de vellón, y cuyo importe se habría de repartir en todo el Reino, estableciendo el Reino la cuota correspondiente a cada uno.

${ }^{35}$ A. Dominguez Ortiz, Crisis y decadencia...Ob. cit., pag.106, nota 15 (Biblioteca Nacional: Manuscritos, 6754, f.307). 
Como vemos, la intención del rey Felipe IV de clausurar las Cortes por la absoluta falta de apoyo de los procuradores a sus peticiones, que así lo expresan paladinamente en la Consulta que elevan al Monarca, con la reacción de este de que finalizasen las reuniones de los procuradores, tuvo un efecto fulminante sobre la actitud de estos, que después de dos años de reuniones seguían oponiéndose a prestar la menor ayuda a la Corona y, como hemos leído en la Consulta que dirigen al Rey, a pesar de su esmerado y ceremonioso estilo barroco, no pueden disimular el cinismo de sus argumentaciones, y no solamente reconocen los fraudes que se hacían a la Hacienda Real, pues siempre se recauda la misma cantidad o menos en sus circunscripciones fiscales, aunque se hayan aumentado las figuras tributarias y los tipos de estas, sino que al final encomiendan a Dios los problemas de la Monarquía. Pero el simple hecho de que Felipe IV manifieste que puede y quiere clausurar unas Cortes que no han satisfecho en ningún grado sus peticiones, de llevarse a cabo podría suponer una ruptura de resultados imprevisibles, y como antes hemos referido acerca de la relación política entre las ciudades y la Corona se había preterido seguir un modelo pactista, de participación y no de enfrentamiento, aunque tratando de conseguir las ciudades sus propósitos por la vía del control de la Monarquía, todo ello hace cambiar radicalmente su obstinada oposición y en el breve plazo que habia hasta el día 23 de diciembre desaparecen todos los razonamientos con que se habian rechazado los medios pedidos por el Rey, y se nota que también se ha producido una intensa labor entre bastidores, pues ahora no se habla de dar cinco nuevos votos a Cortes, sino solamente dos; también es posible que no se tuviese certeza de que hubiera cinco ciudades o regiones efectivamente dispuestas para pagar el precio que la Hacienda Real percibiría por la venta de esos privilegios, y así se preferiría ir a lo seguro y confirmado de aquellos que habían manifestado su propósito firme de entrar en las Cortes. Por el valor que para la historia de Extremadura tiene la consecución del voto en Cortes, transcribimos la parte de la sesión en que se debatió y votó este asunto, pues además el contraste entre las distintas opiniones que se manifestaron el debate es ciertamente enriquecedor:

"Votó el Reyno sobre el servicio de S. M. tocante a que pueda beneficiar la venta de dos votos en Cortes de dos ciudades de estos reynos y los votos que se dieron son los siguientes:

Los señores don Juan Franzisco de Salamanca, don Luis Montesinos, don Joseph de la Calle, don Franzisco de Laredo, don Franzisco Galtero y dos Matheo de Valdés dijeron que en este medio se votó a diez de este presente mes, en el qual se representó a $S$. $M$. los inconvinientes que se ofrecían, a los quales no se a respondido satisfaciendo las dudas propuestas, y respecto de los dichos inconvinientes y de que el Reyno a servido a servido a S. M. para 
la campaña que viene con un millón de efectos promptos que parece que en el estado que se hallan estos Reynos es lo más que se puede dar, por aora no se conforma con este medio por ser totalmente opuesto a servicio de S.M.

El señor don Juan de Cañas dijo que era en lebantar la condición que prohíbe el no acrecentar votos en Cortes para que mande S. M. beneficiar dos ciudades más de las que tienen oy voto en dichas Cortes, con calidad y condición que no pueda adquirir preheminencia alguna más de la que tienen oy las demás ciudades y con que S. M. se sirva dar su fee y palabra real de que no se acrecentarán más, que sólo por esta vez alza la dicha condición de millones, dejándola en su fuerza y vigor para adelante y con que la dicha ciudad a quien diere la dicha preheminencia y voto en Cortes no pueda ussar de arbitrios para su paga, assi generales como particulares en las quatro especies que están señaladas para la paga de sisa ni de otros repartimientos.

El señor don Franzisco de Valdés dijo que es en votar lo mismo que a votado en este negocio, que es no haber lugar por aora para vender estos dos officios atento a la notoriedad y perjuicio que son a S. M. Dios le guarde, y a las ciudades en contravención de sus preheminencias, y en particular de la de Sevilla que lo tiene capitulado y pagado expresamente como consta del assiento que hizo con el señor don Lorenzo de Cabrera, sirviendo a S. M. con quinientos mil ducados que tiene pagados como consta de las cartas de pago que están pressentadas, por lo qual hablando con el respeto que debe es en suplicar al Reyno no vote estas procuraciones de Cortes, pues es notorio ser en perjuicio de tercero $y$ de su ziudad que to tiene comprado y pagado como es notorio, $y$ en su nombre, por si el Reyno passare lo contario, hace todas las protestas que puede y debe para guarda de su dinero y pide zertificación y requiere a los señores secretarios de Reyno lo inserten con lo que el Reyno passare, pues todo es el maior servicio de $S$. $M$. en que se a reconocido es de su maior servicio no augmentar mas procuradores de Cortes, pues quando no fuera mas que los gastos que la Real Hacienda tendrá y si esto se concediera, aunque se ponga por condición no se heche en las quatro especies, las ziudades an de pedir facultad para hechar tributo y gabela, de conocido montara mas los daños que a de caussar esto que conceder a S. M. un millón y su valor a de ser tan corto quanto se reconocera, $y$ buelbe a supplicar al Reyno humildemente considere estas razones que lleva votadas y que sus poderes no se estieden a derogar las preheminencias de las ziudades pues es notoria la nullidad.

Los señores don Diego de los Rios, don Martín de Guzmán, don Franzisco Martín de Avilés, dijeron son del mesmo parecer que lo fue el dicho señor don Diego de los Rios, en siete de este mismo mes que se votó este negocio y fue alzar la condición de millones que prohíbe no llame S. M. más ziudades a Cortes de las que oy concurren, y que pudiese vender los cinco votos que $S$. M. tiene mandado proponer al Reyno y lo mismo votan aora.

Los señores conde de Altamira, vizconde de Ledesma, don Francisco Arévalo de Zuazo, capitán Juan de Segovia, don Julián Árias, don Antonio del 
Hierro, don Diego Vázquez de Aldana, don Francisco de Salcedo, don Diego Gutierrez de Montalvo, don Antonio Verla de Tapia, don Antonio Pacheco Triviño, don Juan Fernández de Alarcón y don Juan Pinar, dijeron que reconociendo las necessidades con que $S$. $M$. se halla y quan precisso era que el Reyno de su parte assista a ellas como tan interessado en los buenos subcesos y conservación de eta Monarquía, continuando con el celo que siempre a mostrado, y particularmente en las ocassiones que en estas Cortes se an ofrecido = son en que S. M. pueda beneficiar la venta de dos votos en Cortes de dos ciudades de estos Reynos, las que fuere servido con calidad que la paga y satisfacción de lo que por ellos offrecieren no a de servir ni se a de poder hechar en contribución sobre las quatro especies ni en otra cosa alguna que sea en daño de pobres ni en que ellos aian de contribuir, y con que el lugar que an de tener en las Cortes no sea señalado sino que aian de concurrir como las demas provincias guardando el estilo que con ellas se observa. $Y$ con que S. M. a de dar su fee y palabra real de no pedir al Reyno consentimiento para que otra ninguna ciudad o villa de estos Reynos pueda tener voto en Cortes, porque para en quanto a estos dos votos solamente y no mas se alza la condición de millones que lo prohíbe, quedando en su fuerza y vigor para lo de más adelante.

Los señores don Joseph Crema y don Melchor de la Vastida dijeron eran como el señor conde de Altamira, sin perjuicio de las ciudades que tienen privilegio en contrario, a las quales no es su animo perjudicar.

El señor don Diego de Salvatierra dijo supplica al reyno repressente a S. M. los inconvinientes que ressultan a su real servicio de la venta de las dichas dos procuraciones de Cortes, y si por maior parte saliere el dar consentimiento para ellas desde luego en nombre de su ziudad, $y$ en virtud del poder que tiene lo contradice, protesta y apela, y pide justificación a los secretarios y les requiere la den.

El señor don Diego Ordóñez dijo que por las razones que el Reyno repressentó a S. M. que Dios guarde, enl la consulta que se le hizo de quanto perjuicio era este servicio por haber de cargar sobre los pobres lo que ofrecieren las ciudades que comprar en esta preheminencia, y aviendo de ser a costa de los regidores de ellas es de muy poco util para su real servicio por estas caussas, $y$ por parescerle que es en perjucio de los privilegios e ynmemorial preheminencia de las cavezas de Reyno que oy son, no se conforma por aora con este servicio.

El señor don Manuel Henrriquez dijo que no se conforma con este medio.

El señor Gerónimo Hurtado dijo que atento a las pressentes necessidades de S. M. es en alzar la condición por esta vez para que se puedan vender dos procuraciones de Cortes sin perjuicio de tercero, $y$ assimismo que pues es util 
y grandeza de las ziudades y los regidores doblan el valor de sus officios, que ellos aian de pagar la compra, y siendo de otra suerte no viene en ello.

Los señores conde de Hernan Nuñez, don Martín de Guzmán, don Francisco Martín de Avilés, don Juan de Cañas, don Melchor de la Vastida y Ge. rónimo Hurtado dijeron se regulaban al voto del señor conde de Altamira.

Regulados los votos, salió por mayor parte el del señor conde de Altamira".

Y de este modo, el día 21 de diciembre de 1650, el Reino aprobó la ampliación de ciudades de voto en Cortes en otras dos, pasando a ser veintiuna las ciudades de Castilla que participarían. Con ello se abría efectivamente la posibilidad de que Extremadura tuviese voz propia en las Cortes, pero este requería previamente una negociación con el Consejo de Hacienda.

Dejamos en este punto la narración de las reuniones de Cortes, cuya clausura, tan inmediata como quería el Rey, se fue prorrogando varias veces tras la aprobación de los tres medios solicitados. No obstante parece conveniente señalar dos cosas: una era la amplia petición de que el pago de estos votos no recayese en las cuatro especies sobre las que se arbitraba la percepción de los Millones, y, en segundo lugar, el que se reconozca paladinamente cómo el valor del oficio de regidor se duplica cuando este tiene la opción de ser procurador en Cortes por pertenecer al concejo de una ciudad con el privilegio del voto.

\section{EL CONTRATO DE COMPRA DEL VOTO POR EXTREMADURA}

La incorporación de Extremadura a las Cortes ya estaba prenegociada desde mucho antes, pues en el año 1648 el conde de la Roca había informado al concejo de Mérida de que se presentaba una buena ocasión para conseguir el voto en Cortes, aunque ello supondría un gasto importante, y a finales de ese mismo año el concejo de Badajoz había dado una carta de poder para conseguir el voto y compartirlo con otras ciudades extremeñas ${ }^{36}$; poco después de la sesión en que se aprobó la ampliación del número de ciudades en Cortes se conoció el importe que solicitaba la Hacienda Real por la concesión de tal merced, y que había sido establecido en cien mil ducados ${ }^{37}$, proponiéndose que este pago se efectuara abonando una mitad el concejo y la otra los regidores, es decir, el común de los vecinos

\footnotetext{
${ }^{36}$ Archivo Histórico de Badajoz (AHB,: Libro de Actas, sesión del 4 de diciembre de 1648.

${ }^{37}$ AHB, Libro de Actas, sesión del 8 de febrero de 1649.
} 
de cada una de las ciudades que se unieran en el disfrute del privilegio del voto tendrían que pechar con la mitad del precio, y los regidores de ellas con la otra mitad.

Producida la aprobación de las Cortes, por una Real Cédula firmada en El Pardo el dia 23 de enero de 1651, Felipe IV comisiona a don Juan de Góngora, del Consejo de Hacienda, para que pusiera en marcha la efectiva venta de los votos que se acrecentaban, cuya tramitación y conclusión, para el que correspondió a Extremadura, conocemos por el Expediente que obra en el Archivo Histórico de Mérida ${ }^{38}$.

Ya durante la discusión en las reuniones de Cortes, antes de que se aprobara la venta de los dos votos y cuando se debatía sobre la procedencia o no de los medios pedidos para servir al Rey, uno de los cuales consistía en la venta a cinco ciudades del privilegio de participación en las Cortes, en la intervención del vizconde de Laguna, procurador por Segovia, manifestó que daba su "consentimiento para que S. M. venda dos procuraciones de Cortes, la una en Andalucia y otra en Extremadura...", con lo que vemos cómo entre los procuradores ya estaba recogido el deseo de algunos concejos de Extremadura de participar mancomunadamente en las Cortes de Castilla, así como otro para una ciudad andaluza, que algunos anunciaron que sería Écija, pero luego no sería así pues la que acompañó a Extremadura en su entrada en las Cortes fue la ciudad de Palencia.

Por parte de Extremadura comparece en la corte, para negociar y formalizar el contrato, una comisión formada por don Blas de Alarcón Pacheco, regidor de Trujillo, don Juan Antonio de Vera, regidor de Mérida, Alonso García Silíceo, alguacil mayor de Badajoz, junto a los regidores don Bernardino Morante, don Francisco de Chaves Sotomayor y don Juan de Vargas, todos del concejo pacense; don Gabriel de Saavedra y don Francisco Antonio de Obando Rol y Cerda, por el concejo de Cáceres; don Agustín Guerrero de Guzmán y don Francisco de Aldana, con poderes de la villa de Alcántara, y don Juan Antonio de Vera, conde de la Roca, el marqués de Pomar y Monroy y Joseph de Oliva que representaban al concejo de Plasencia ${ }^{42}$. Llama la atención ver al conde de la Roca, que por una parte es el único representante del concejo emeritense y del que no se cita que es regidor perpetuo de su cabildo y sí que es miembro de los reales concejos de Hacienda y Guerra, lo que explica que tres años antes hubiera avisado a los regidores de Mérida sobre la oportunidad que se presentaba de conseguir el voto en Cortes y además facilitaría posiblemente las negociaciones con Góngora; y por otro lacio vemos al señor de Vera con poderes del concejo de Plasencia, del cual comparecen además dos regidores.

\footnotetext{
${ }^{38}$ Archivo Histórico de Mérida, Legajo 9, Carpeta 64 (En lo sucesivo: Expediente.).
} 
El contrato se inicia recordando los servicios que la Provincia de Extremadura y sus ciudades y villas han hecho al Rey, y especialmente durante los últimos "once continuos años con la sublevación de Portugal, en que no sólo ha servido y sirve como las demas provincias del Reyno sino con particular demostración, acudiendo a su costa con tantos y tan continuos socorros de gente y dinero y cuartel ordinario de la caballería y ejército y daños grades que han recibido sus ciudades, villas y lugares" se pide la merced al Rey de apartarla de Salamanca, que hasta entonces hablaba en las Cortes por la Provincia de Extremadura, y que en adelante hubiera procuradores de Cortes con voz y voto por Extremadura, en igualdad con las demás ciudades que concurren en las Cortes, para lo cual ha sido aceptado el contrato presentado por don Juan de Góngora, en que se estipulaba servir a la Corona con 80.000 ducados, a pagar en dos plazos de seis meses, en un año, a contar desde el día 10 de octubre de 1.651, momento en que se aprobó el contrato en el Consejo de Hacienda; determinándose que la mitad de ese importe "lo hayan de pagar cada ciudad o villa de sus propios y rentas y de los arbitrios que propusiesen y se les concediere" y la otra mitad la aportarían los propios regidores. Sobre esta venta, la Hacienda real siguió percibiendo además de su importe la media annata, que se cobraban quincenalmente, y que para Mérida, en 1765, ascendía a 7.353 reales $^{39}$.

También se precisaba que las ciudades o villas a las que tocara la suerte de asistir a las Cortes habian de "hablar y votar... por toda la Provincia». Se segregaba de Salamanca la administración del Servicio de Millones correspondiente al territorio de la provincia extremeña, y se establecerían receptorías en cada una de las ciudades y villas de Extremadura que gozaran del voto en Cortes, y para ello esta planta administrativa se completaría en Cáceres, Alcántara y Jerez que carecian de oficinas recaudadoras, pero al pasar el contrato por el Consejo de Hacienda se determinó que "en cuanto a las tesorerías no haya más de las cinco que al presente se sirven y las otras tres de las ciudades y villas donde no las hay se agreguen a las cinco, o se haga una tesorería de todas o mudando en cada Cortes a la ciudad a quien tocare".

Para determinar el turno con que las ciudades y villas extremeñas asistirían a las reuniones de Cortes se establecía el habitual procedimiento del sorteo, mediante la introducción de bolas, con el nombre de una ciudad en cada una de ellas, en un cántaro para que las extrajese «un niño de edad de seis o siete años", indicándose que las dos primeras bolas que se extrajesen serían las correspondientes a las dos primera ciudades que en-

${ }^{39}$ A. If. M., Legajo 21, carpeta 11. (carta de pago de quinquenios de la media annata por la merced del voto en Cortes, Badajoz 4 de marzo de 1765). 
viarían un regidor cada una a la primera convocatoria de Cortes, las de la tercera y cuarta bola irían a la siguiente, y los de la quinta y sexta a la tercera convocatoria, "con delaración que desde una convocatoria de Cortes a otra las ciudades o villas a quienes tocare el turno de aquellas Cortes hayan de tener en si ellas su Ayuntamiento y regidores la correspodencia y administración general de los Millones y demás servicios concedidos"... "Y porque podría embargar la execución y cumplimiento de mis reales Órdenes si las dos ciudades o villas juntas a quien tocare el turno de las Cortes hubiesen de tener la correspondencia de la Administracion real de los servicios, se declara que para todo lo que durare el primero turno en las primeras quatro Cortes hasta que la convocatoria de las quintas ha de tener la correspondencia y administración general de los servicios en la ciudad o villa a quien en cada una de las Cortes saliere primero la suerte, de forma que según el sorteo que se ha de hacer vendrán a ser las ciudades y villas a quien tocare la primera tercera quinta y septima suerte, y de las quintas Cortes hasta la convocatoria de las onzenas ha de tocar la dicha correspondencia superintendencia y administración en los dichos intermedios de convocatoria a convocatoria a las otras ciudades o villas que en el primer turno no la tuvieron para que desta forma se venga a gozar por todas en igualdad".

En previsión de que alguna ciudad o villa de Extremadura no quisiera participar en el voto en Cortes, y para esta negociación no habían enviado representantes Llerena ni Jerez, se decía «que la parte que pudiese tocar a las villas o ciudades que no quisieren gozar se ha de agregar e incorporar en las demas ciudades y villas que quedaren... y se gobernará el turno entre las que quedaren, haciendo lo mismo en la administración". En relación con el turno de los regidores "se declara que llegado el caso de la convocatoria a los a quien tocare y hayan de dar llamamiento expresso por la dicha suerte como se acostumbra en los ayuntamientos para semejante caso y habiendose hecho el dicho llamamiento y juntandose los regidores en su ayuntamiento ha de haber dos cantaros y en el uno se har de meter tantas bolas huecas como oficios de regidores hubiesen pagado su parte de la dicha merced...y en cada bola el nombre del regidor o dueño del oficio por quien estuviere el derecho de la suerte asi de ausentes como presentes, y en el otro cantaro tantas bolas como cedulas en blanco menos una en la cual se diga Procurador de Cortes, y unas bolas y otras bolas se han de sacar por mano de un niño de edad de siete años y no más, sacando el nombre primero y siguientemente se ha de sacar del otro cantaro la otra bola, y al que le saliere la dicha suerte ha de quedar por tal Procurador de Cortes y la ciudad o villa le ha de dar sus poderes como se acostumbra, $y$ al oficio que le hubiere tocado la dicha suerte no ha de volver a entrar en ella otra vez hasta que todos los demas oficios hayan gozado de la dicha suerte".

El dia 24 de octubre de 1651, se notificaba, mediante unas provisiones reales, a los concejos de Llerena y Jerez que se había dado por finalizada 
la tramitación del contrato y se les daba un plazo para incorporarse a él, advirtiéndoles que transcurrido el mismo quedarían perpetuamente excluidas de participar en el privilegio del voto en Cortes por Extremadura. Similar advertencia se hacía para los regidores que no pagasen la parte que les correspondiese en su concejo por la compra de la merced del voto, determinándose que el resto de los regidores quedaba mancomunado para el pago y que se excluirían del sorteo a los que no hubiesen aportado su parte. También se daban normas para los casos de ausencia, fallecimiento o traslado de residencia de los regidores con derecho a la procuraduría de Cortes. Por un auto de 27 de enero de 1652, dirigido a los concejos de Llerena y Jerez, se les notificaba que "al no haber enviado sus poderes para obligarse a la paga de la parte que tocaba a cada una dellas, y pasádose el término en que lo habian de hacer... se declaró por no parte a las ciudades de Xerez y Llerena y por excluidas del voto en Cortes y que las ciudades de Badajoz, Mérida, Plasencia, Truxillo y villas de Cáceres y Alcántara en quien había quedado el dicho voto".

"Para execución y cumplimiento de lo dispuesto por una de las condiciones de la escritura del contrato que da la forma que se a de tener para echar la suerte del voto, habiéndose juntado en el convento de San Martín, de la orden de San Benito, de la villa de Madrid, en dos de febrero de 1652, la muy noble y muy leal Provincia de Extremadura y por ella y en su nombre, por la ciudad de Mérida el conde de la Roca, por la ciudad de Badajoz Alonso Garcia Silíceo, por la de Truxillo don Blas de Alarcón Pacheco, por la villa de Cáceres don Gabriel de Sahavedra, por la ciudad de Plasencia Joseph de Oliva y por la villa de Alcántara don Agustín Guerrero de Guzmán, por ante el escribano Francisco Diaz, habiéndose procedido todos los requisitos que en semexantes casos se acostumbra y traidose para este efecto los cantaros y bolillas de plata en que la villa de Madrid hecha las suertes de Cortes y escritose seis papeles, cada uno con el nombre de la ciudad y villa de quien cada uno de los dichos Conde de la Roca, Alonso García Silíceo, don Blas de Alarcón, don Gabriel de Sahavedra, Joseph de Oliva y don Agustín Guerrero de Guzmán tiene poder y dadosele para que de su mano la metiere en las dichas bolillas y cerrase el tornillo della y hechase en el cantaro y habiendo cada uno leido el nombre de su ciudad o villa y metidola en la bolilla de plata y cerrado el tornillo della se juntaron metieron y echaron las dichas seis bolillas en el dicho cantaro de plata y por un niño de tres años poco mas o menos se sacaron las dichas suertes y la primera fue una bolilla en que estaba escrito el nombre de la ciudad de Truxillo, la cual como primera quedó con primero voto para las primeras Cortes, y luego sacó otra boloilla en que estaba escrito el nombre de la ciudad de Mérida, con que las dichas ciudades quedaron nombradas y sorteadas para las primeras Cortes, y luego sacó otra bolilla y en el papel que en ella estaba escrito el nombre de la ciudad de 
Badajoz, con que para las segundas Cortes quedo en el primero voto, y luego sacó otra bolilla que tenía escrito el nombre de la villa de Cáceres, que también quedó para las segundas Cortes, y para las terceras y últimas sacó otra bolilla que tenía escrito en ella el nombre de la villa de Alcántara, con que vino a quedar con primero voto para las terceras Cortes, y luego. sacó otra bolilla, que fue la última, que tenía escrito el nombre de la ciudad de Plasencia, con que quedó para las terceras Cortes, con que se acabó la suerte". En aplicación de los resultados del sorteo antes referido, para participar en las primeras reuniones de Cortes, como representantes de ciudades titulares del privilegio del voto de Extremadura, asistieron don Pedro Jacinto Calderón y Chaves, regidor del concejo trujillano, y don Diego Mesía de Ocampo, que lo era del concejo emeritense .

El día 31 de agosto de 1665, Felipe IV ordena se convoquen las Cortes para que se reuniesen el 15 de octubre siguiente en Madrid, con el fin de prestar juramento al príncipe Carlos como heredero de la Corona, pero aquellos eran los días últimos de la vida del monarca, que murió el 17 de septiembre, y ya sabemos cómo la reina viuda, actuando como gobernadora del reino según las disposiciones testamentarias, dispuso la suspensión de la citada convocatoria de Cortes, que ya no volverían a reunirse en Castilla mientras la dinastía de los Austria fue titular de la Corona .

Sorprende pues una R. P., de 10 de junio de 1666, dirigida «a los concejos, justicias y regimientos de ciudades y villas de la Provincia de Extremadura", comunicándoles cómo en el Consejo del día 9 se había presentado una petición de la ciudad de Llerena en la que se decía "que abiendose servido de hacer ciudad de voto en Cortes a la Provincia de Extremadura sirviendo con 80.000 ducados repartidos entre seis ciudades $y$ dos villas este merced se acetó por cinco regidores de algunas de las ciudades de dicha Provincia sin que interviniese a ello la ciudad de Llerena... Y es asi que abiendose dado despacho por el licenciado don Juan de Góngora para hacer saber dicho contrato a dicha ciudad sa notificó el despacho a cinco regidores propietarios que sirvían por nombramiento de los dueños de los oficios sin notificar a todos los que tenían oficio con voto en dicho ayuntamiento y... ni los que sirvian dieron cuenta a los dueños ni trataron de acudir a este negocio ni a obligarse por no resultarles de utilidad alguna, y los regidores que asistian en esta Corte por las otras ciudades haciendo relacion de que la diligencia se habia hecho lexitimamente y que no avia parecido en el término de los treinta dias la dicha ciudad de Llerena y pidieron que se declarase por no parte y que la escritura se hiciese con ellos para que pudiesen sortear el turno como en efecto lo consiguieron y excutaron" " ; prosigue el texto manifestando su compromiso de sa-

\footnotetext{
${ }^{40}$ A. H. M., Legajo 11, carpeta 24 .
} 
tisfacer a las ciudades y villas acogidas al voto el dinero que se repartió correspondiente a Llerena, y alegan que en su momento no fue "posible acudir a este negocio por hallarse ocupados los rexidores y vecinos de dicha ciudad en las ocasiones que se ofrecian de la guerra", razonamiento este que se podría entender lo comprendieran desde la perspectiva de la corte, por cuanto era el Real Ejército de Extremadura el que llevaba el peso de las campañas militares contra Portugal, y que ya en su propia denominación se refiere a todo el ámbito extremeño: pero para las ciudades que compraron el voto, y que ahora deben responder ante el Rey de la procedencia o no de la petición de Llerena, el argumento expuesto era escasamente convincente, porque si la guerra contra Portugal habia convulsionado todas las estructuras sociales en algunas ciudades, era indudable que como Badajoz pocas había sufrido ese azote apocalíptico, y, en segundo lugar, del grupo de las ciudades de voto, Alcántara y Mérida también conocían en su mayor intensidad las consecuencias del conflicto, y todas ellas eran las que, en 1650 y 1651 , hicieron las gestiones inherentes a la consecución del voto en Cortes, sin que los avatares de la guerra que se reñía en su propio suelo, como frente de batalla o como retaguardia inmediata, mermaran el tiempo y la dedicación necesaria para estas gestiones. Aparte de esta excusa, lo que parece más cierto es que los regidores propietarios de los oficios del concejo de Llerena estaban totalmente desentendidos tanto de la vida del concejo como de las posibilidades políticas que se presentaban, pues además ni siquiera tenían relación para estos asuntos con las personas que ocupaban en sus nombres las regidurías, lo que manifiesta otro aspecto negativo de la patrimonialización de los oficios y, a la vez, resalta cómo los regidores estaban muy alejados de los problemas y expectativas del común de los vecinos dentro del ámbito institucional del concejo.

Desconozco la respuesta a esta Provisión Real de las ciudades y villas de Extremadura que gozaban del voto, pero lo cierto es que Llerena no llegó a compartir el voto en Cortes de Extremadura. Por otra parte, es un tanto inexplicable ese deseo de Llerena para participar en las Cortes cuando un año antes la Reina-gobernadora había suspendido las reuniones de Cortes. Es de intuir que la intención de los regidores llerenenses no iría tanto por las propias Cortes como por la posibilidad que ello les daría de tener una participación en la administración de los Millones, que al suspenderse las Cortes hizo que la ciudad que ejercía su turno en ese momento se quedase en él, sin que las otras tuvieran ya la oportunidad de participar en esa administración, por cuanto la rotación estaba ligada a las convocatorias de las Cortes que ahora ya no se producían, y que originaría un conflicto entre las ciudades, del que se hizo una relación al Consejo Real por causa del litigio planteado por Plasencia, Alcántara, Mérida y Trujillo, de una parte, frente a Badajoz y Cáceres por otra ${ }^{41}$, pues como

"A. H. M., Legajo 13, carpeta 23. 
hemos visto por el sorteo que estableció el orden de participación, los procuradores de Trujillo y Mérida acudieron a las Cortes de 1658, y los de Badajoz y Cáceres a las que concluyeron en el año 1664, por lo que estos continuaron ejerciendo en el hueco entre convocatorias, que ahora se había hecho indefinido, pero que tienen un importante papel por la Comisión de Millones en la que pueden participar, porque entienden «que la prorrogación de Millones tuviese los mismos efectos que la celebración de nuevas Cortes", y todo ello dio lugar a un expediente que se inició en el año1697, al amparo de un Decreto Real de 16 de junio de 1694 en el que se dice: "está resuelto que la representación de estos reynos se mantenga $y$ conserve en los quatro procuradores de Cortes que asisten y asistieren en la Sala de Millones del Consejo de Hacienda, y que respecto de no haber sorteado las ciudades la suerte de procuradores comisarios que an de servir durante el sexenio de la nueva prorrogación, cesando los actuales $y$ entrando en su lugar aquellos a quien tocare la suerte executandose en la forma que se acostumbra quando se disuelven las Cortes y que en cada prorrogación subceda lo mismo para que todas las ciudades y sus capitulares gocen de esta preeminencia". Años después, por un Auto del Consejo emitido el 17 de diciembre de 1698, se falla que "visto por los señores del Consexo el pleito entre la ciudad de Plasencia y villa de Alcántara... y las ciudades de Mérida y Truxillo de la una parte y de la otra la ciudad de Badajoz y villa de Cáceres sobre el uso de voto de Diputación de Millones. Dixeron que declaraban y declararon haber llegado el caso de gozar la dicha ciudad de Plasencia y villa de Alcántara de el uso de voto en Cortes y haber consumido su turno la ciudad de Badajoz y villa de Cáceres con la nueva concesión de Millones que se hizo por el Reyno" ${ }^{42}$.

La lectura de las Actas de las reuniones de Cortes celebradas entre los años 1650 y 1651 , etapa durante la cual se aprobó la venta del voto para Extremadura, deja el ánimo sobrecogido porque, a lo largo de tantos días de sesiones, no hay ni una sola mención a la situación real de la Monarquia española, tan duramente castigada en los recién firmados acuerdos comprendidos en el Tratado de Westfalia (1648), que, entre otras cuestiones, habían supuesto la pérdida de nuestra hegemonía en Europa así como la derrota plena de la política de los Habsburgos, y, lo que era todavía peor, la implantación del hito que señalaba el final de una trayectoria histórica y el inicio de una declinación.

Tampoco se hallan indicios de que los personajes que están gestionando la consecución del volo en Cortes para Extremadura hagan eso como la aportación de una comunidad, hasta ese momento marginada de la interlocución directa con la Corona, que con su voz y voto podría contribuir a enderezar el rumbo de la Monarquía; muy al contrario, por una parte ape-

${ }^{42}$ A. H. M., Legajo 13, carpeta 23. 
nas mencionan el problema de la guerra con Portugal, que en aquellos momentos llevaba ya diez años asolando campos y ciudades, cobrando vidas, arruinando a los concejos y despoblando los pueblos, y cuando lo hacen, como hemos visto con Llerena al pretender tardíamente incorporarse al derecho y uso del voto, es con una argumentación falaz; y por otro lado, vemos en ese episodio y en el del pleito contra Badajoz y Cáceres, la falta de armonía y el descarado abuso de los derecho de unos frente a otros, $y$ todas estas actitudes vuelven a hacernos recordar el texto de Ortega sobre el particularismo ${ }^{43}$, que aunque él lo analiza en el contexto de la España Contemporánea, bien podemos decir que había precedentes sobrados de ese carácter insolidario y egoísta en estos grupos oligárquicos en la Castilla del siglo XVII.

Por todo esto, hemos de coiricidir con Palacio Atard cuando, al explicar la crisis del siglo XVII, dice que "ocurre en esta segunda mitad del siglo... el asalto al poder por esa oligarquía claudicante...La corrupción suele ser compañera de la desgracia, y esto ocurrió entonces en España. La aristocracia, la nobleza, las clases altas, las que estaban llamadas a dar ejemplo y a ser las más conservadoras de la virtud política, sólo piensan en sus pequeños egoísmos, sin que la nación signifique para ellas otra cosa que un palacio abandonado en el que puede entrarse a saco" " ${ }^{44}$. Durísimo es el juicio que merecen a Palacio Atard estos grupos que dominan el gobierno de la nación y de los pueblos castellanos, y en su expresión señala a la corrupción como la causa nuclear de todos los problemas, y a esta altura del presente estudio es nítidamente visible que la corrupción carcomía las viejas estructuras de la administración pública.

Pero dentro de este panorama desolador, y siguiendo la directriz de nuestro trabajo, hay un aspecto que nos parece sumamente positivo y es que al concederse el voto en las Cortes de Castilla a la provincia de Extremadura, señalándose que habrian de hacer de cabeza de la Provincia las ciudades de Mérida, Trujillo, Plasencia, Badajoz, y las villas de Cáceres y Alcántara, y que todas ellas habrían de hablar y votar en Cortes por toda la Provincia de Extremadura. $Y$ es que si se consideraba ya una modernización política en Castilla la ampliación del número de ciudades con voto en Cortes, aquí se está confirmando un salto cualitativo muy importante por su trascendencia para el futuro, pues, al igual que se había dado a Galicia unos pocos años antes, ahora ya no se vincula el voto a una ciudad sino que se le da un valor territorial al tener que compartirlo entre varias ciudades; es decir, aparece embrionariamente un principio que alcanzará pleno valor cuando haya desaparecido el Antiguo Régimen, y que hoy está ple-

43 J. Ortega y Gasset, España invertebrada. Madrid, 1984, pgs. 44 a 51.

44 V. Palacio Atard, España en el siglo XVII. Madrid, 1987, pag. 87. 
namente vigente: el de la representación territorial. Ciertamente, y aunque toda Extremadura iba a estar representada en las Cortes de Castilla mediante el aprovechamiento de un recurso tan viciado como era el de la compra del privilegio entrando en el corrupto mercadeo que utilizaba la Hacienda Real para obtener recursos, la realidad era que solamente se beneficiarían los regidores de los concejos participantes en el nuevo papel que iban a desempeñar.

También es de señalar que el voto en Cortes mancomunado por las seis ciudades y villas para representar a Extremadura, suponía configurar, por primera vez en la Historia de esta región, una institución política que abarcaba a toda la comunidad extremeña, tan fragmentada en territorios de realengo, de señoríos laicos y eclesiásticos y de Órdenes Militares; con las comunidades existentes en la zona al Norte del río Tajo dependiendo de la Real Chancillería de Valladolid, mientras las situadas al Sur estaban dependientes de la de Granada; y fiscalmente subordinadas a la administración de la ciudad de Salamanca, por ser la titular del voto en Cortes donde se englobaba a Extremadura, y de cuya actuación se tenian fundados sentimientos de que no era equitativa al gravar a los concejos extremeños con cuotas superiores a las que les correspondía por su población en el reparto del encabezamiento.

Finalmente, a pesar de tal cúmulo de derrotas militares, fracasos políticos, bancarrotas financieras, tanta dejación de autoridad real en manos de los validos y del aumento de la influencia de grupos oligárquicos en las instituciones de la Monarquía, se mantiene el proceso de avance y consolidación del Estado moderno, y ello se nos hace evidente en la indiscutible afirmación del poder real, que aunque encarnado en monarcas débiles sólo por la determinación de su voluntad personal hemos visto cómo consiguen doblegar la oposición intransigente de una asamblea dominada por intereses particularistas. $Y$ de esta posición, asediada pero no vencida, de la Corona como fuente del poder, se deriva en el pensamiento político que los oficios públicos son todos ellos una merced real, y así Extremadura pudo alcanzar un nuevo estadio en la relación Rey- Reino. 